\title{
THE COLOR EFFECTS OF THE THERAPEUTIC INTERNAL SPACES OF CHILD'S HOSPITALS
}

\author{
Nesma Ashraf Hassan El-Olemy, ${ }^{* 1}$ and Germin Farouk Elgohary ${ }^{2}$ \\ ${ }^{1}$ Department of Architecture, Faculty of Engineering at Shoubra-Banha, University, Egyp \\ ${ }^{2}$ Urban Design and Planning Department,-faculty of Eng., Ain Shams University, Egypt. \\ *Corresponding Author E-mail:nesmaaashraf92@gmail.com.
}

\begin{abstract}
The research summarizes the study of the psychological impact resulting from the use of colors on the sick child, while he is in the internal architectural void in hospitals. It highlights the importance of developing the interior design of children's hospitals and meeting their psychological and physiological needs. Through colors and positively employing them to help the sick child recover and reduce the adverse effects that may affect the psyche of the ill child, it delays his recovery. Therefore, attention must be raised to hospital vacuums' performance because they affect the psychological and health aspects of the patients, especially if the patient is a child. After all, the child's needs are different from other Age groups. The research tests the psychological impact of the interior design of elemental colors on child behavior, needs, and psychology. The theory to reach the results of the favorite colors for children in different age groups through a color questionnaire and its relationship to the child's needs.
\end{abstract}

\section{KEYWORDS: Children's Hospitals, Child Needs, Colors, Interior Spaces, Chakra, and Fong Choy science.}

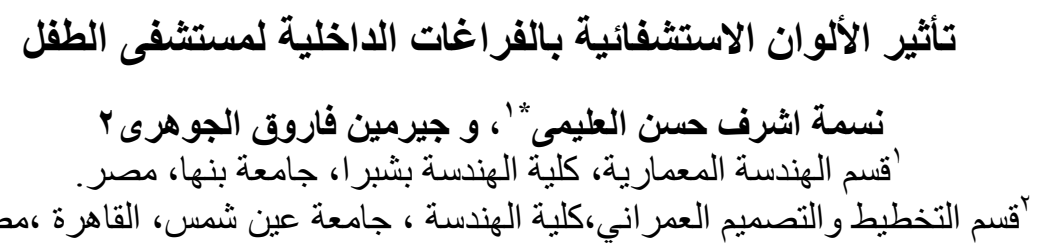

|البريد الاليكتروني للباحث الرئيسي: E-mail:nesmaaashraf92@gmail.com،

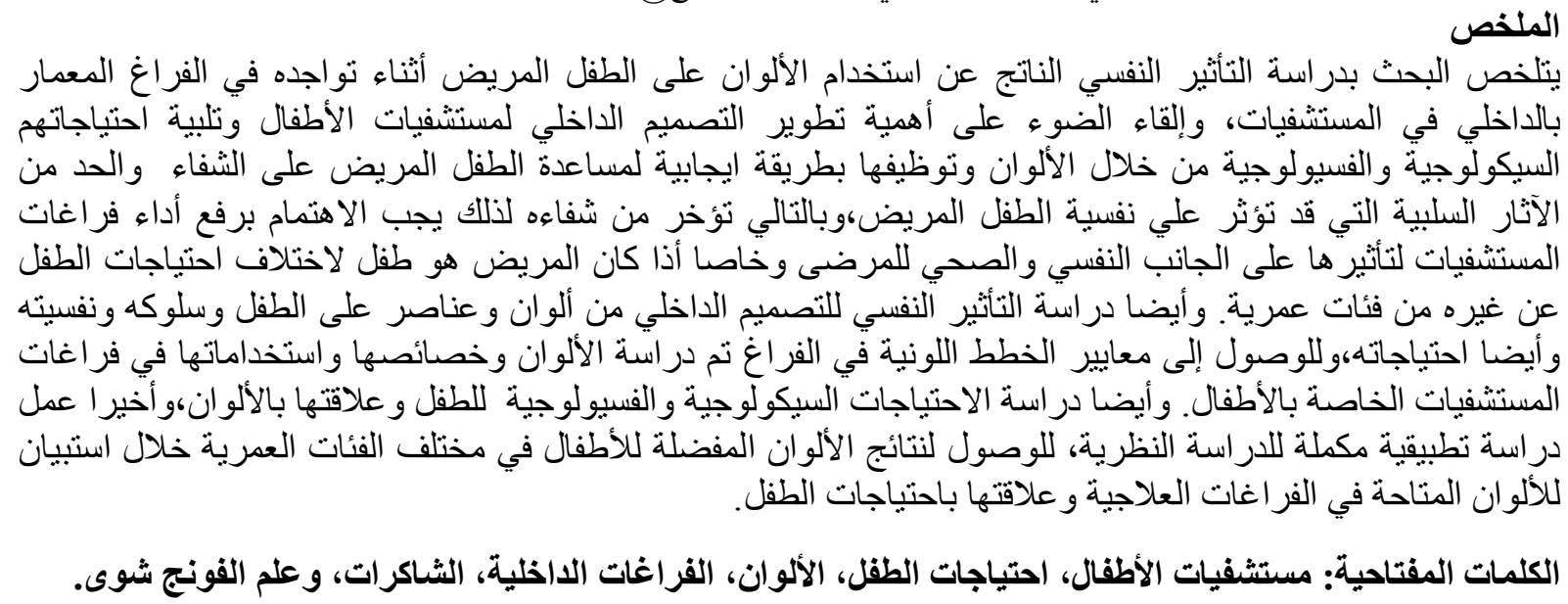




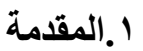

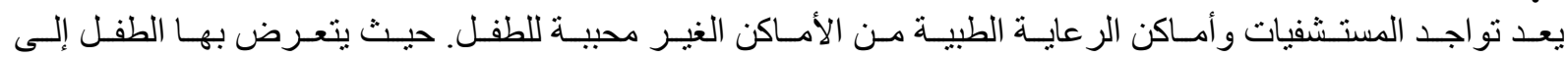

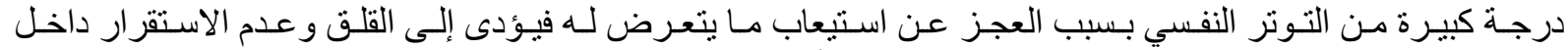

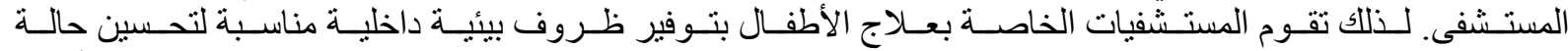

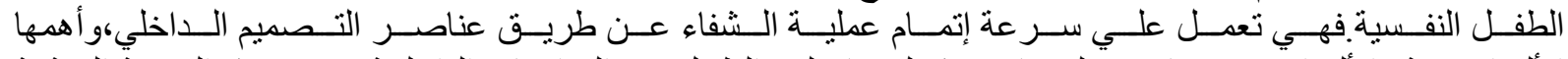

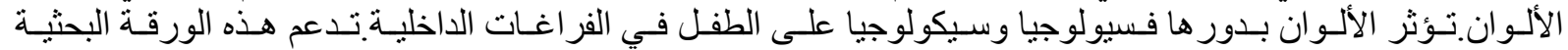

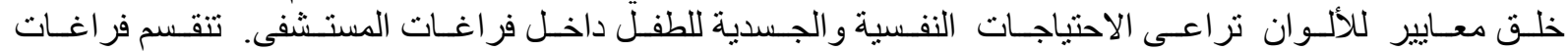

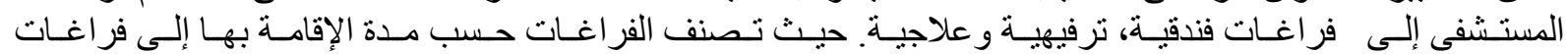

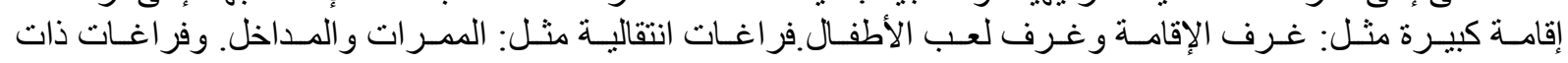

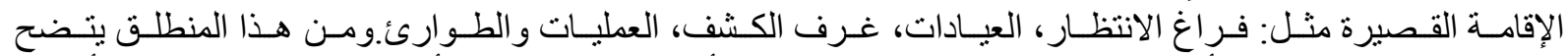

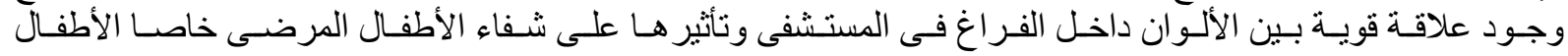
فى الفترة مابين (صفر - Y T) الانة.

ب المشكلة البحثية

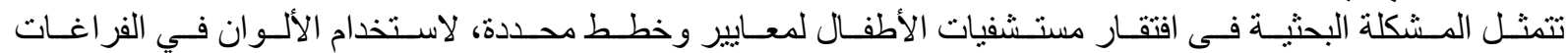

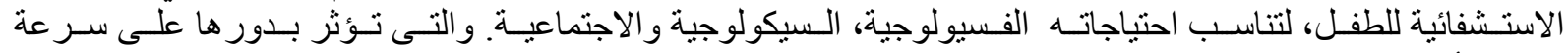

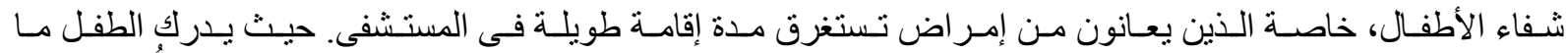

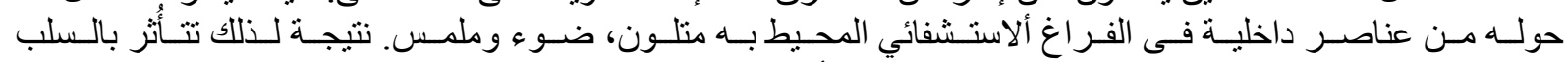

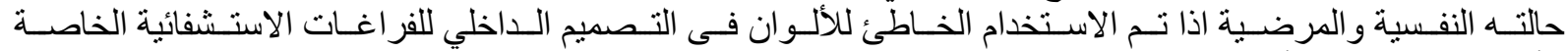
تتأخر عملية الثفاء للأطفال.

الهدف من البحث هو: الاهتمام بالحصول على معايير واشتراطات للألوان الخاصة بالفراغات الاستشفائية للأطفال

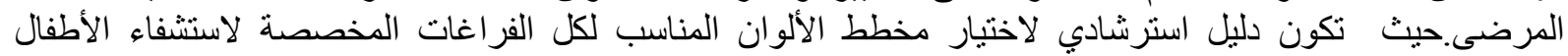

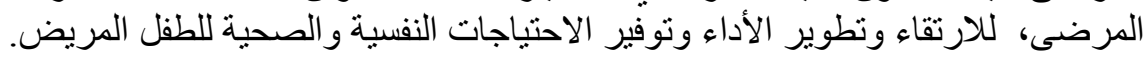

ك ـمنهجية البحث

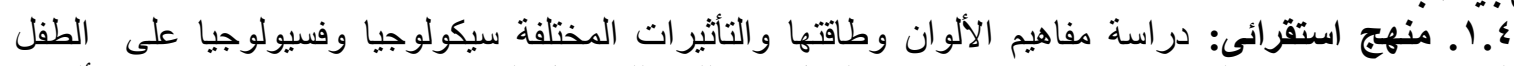

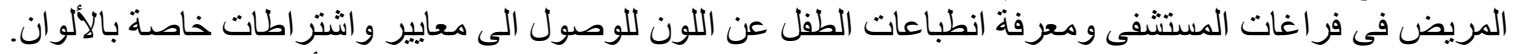

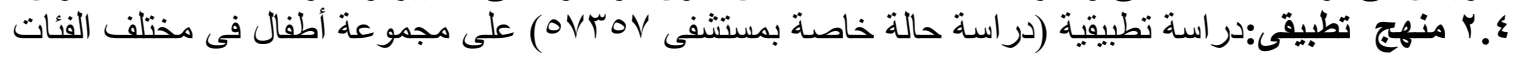
العمرية خلال استبيان لاستتناج الألوان التى يفضلها الأطفال فى فراغاتهم.

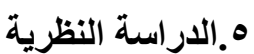

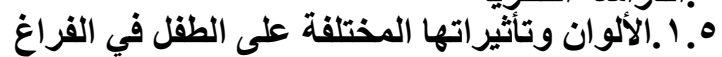
الألوان هي عبارة عن الصفة التي يحملها الجسم، والتئي التي تميزه عن غيره من الأجسام الأخرى. الألوان فيزيائياً هي ما تراه

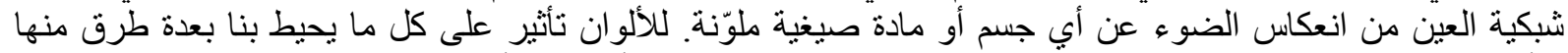

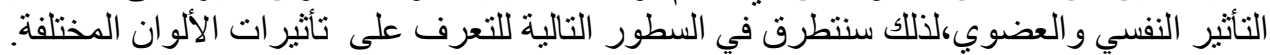

ه. ا. ا.تأثيرات الألوان المختلفة

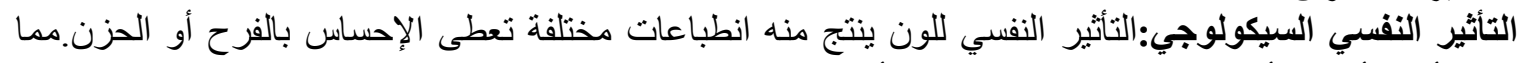

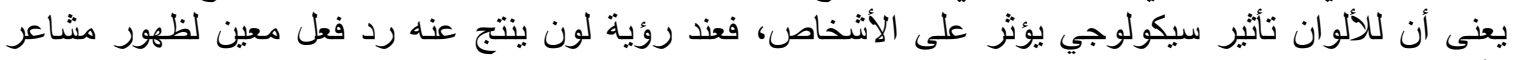

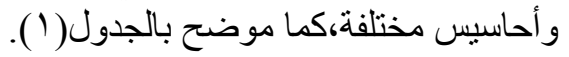
التأثير العضوى الفسيولوجى:للون نأثثر عضوي على الأشخاص وأجسامهم وأعضائهم الحيوية، فمثلاً يؤثر اللون الأني

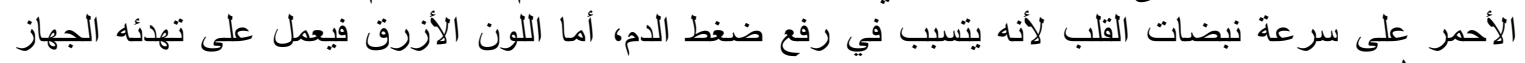
العصبي '،كما موضح بالجدول(r) (r). 


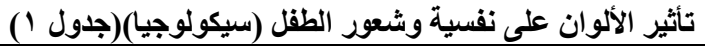

\begin{tabular}{|c|c|c|c|c|c|c|c|c|c|c|}
\hline \multicolumn{11}{|c|}{ جدول( (')يوضح الجدول تأثير الألو ان السيكولوجى (النفسي)على الطفلالمرجع رقم(· ()،(r)(المصدر الباحث). } \\
\hline \multicolumn{10}{|c|}{ التأثير السيكولوجي(النفسي) } & \multirow[t]{3}{*}{ اللون } \\
\hline \multicolumn{3}{|c|}{ شعور سلبي } & \multicolumn{5}{|c|}{ شعور إيجابي } & \multicolumn{2}{|c|}{ جذب الاتتباه } & \\
\hline توتز & خوف & غضب & شجاعة & هدوء & نثاط & ابتهاج & سعادة & الأثارة & خيال & \\
\hline يحفز & & & يحفز & & يحفز & يحفز & يحفز & & يحفز & اصفر \\
\hline بحفز & & بحفز & يحفز & & بحفز & & يحفز & بحفز & & احمر \\
\hline & & & يحفز & & يحفز & يحفز & يحفز & يحفز & & برتقالي \\
\hline & & & & بحفز & & & بحفز & & بحفز & ازرق \\
\hline & & & يحفز & يحفز & & & بحفز & & & اخضر \\
\hline & & يحفز & يحفز & & & & & & يحفز & بنفسجي \\
\hline & & & & & & & يحفز & & & ابيض \\
\hline & يحفز & بحفز & & & & & & & & اسود \\
\hline
\end{tabular}

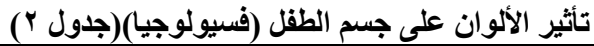

\begin{tabular}{|c|c|c|c|c|c|c|c|c|c|c|}
\hline \multicolumn{11}{|c|}{ 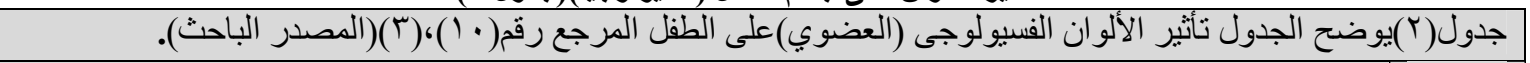 } \\
\hline \multicolumn{10}{|c|}{ التأثير الفسيولوجي(العضوي) } & \multirow[t]{2}{*}{ 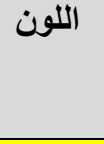 } \\
\hline السرطان & حرارة & القلب & الشهية & المناعة & الاعصاب & الهضم & التنفس & التركيز & ضغط & \\
\hline & & & فاتح & مقوى ( مقى & منشط & 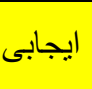 & & منشط & & اصفر \\
\hline & حر ارفح & & فاتح & & & ايجابي & & & الضرفع & احمر \\
\hline & & النبض & فاتحهية & & & ايجابى & & & & برتقالي \\
\hline بعالج & & النبض & & & مهtيء & & مهديء & & مخفض & ازرق \\
\hline 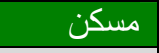 & مخفض & 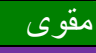 & & & & & ههديء & & مخفض & اخضر \\
\hline & & إيجابى & & & & & ايجابى & & & بنافسجي \\
\hline & & & & 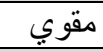 & & & ايجابى & & & 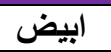 \\
\hline & & & لشثبية & & & & & & & اسود \\
\hline
\end{tabular}

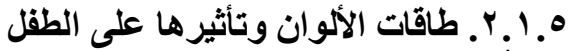

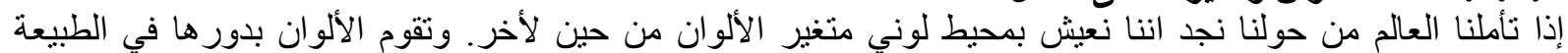

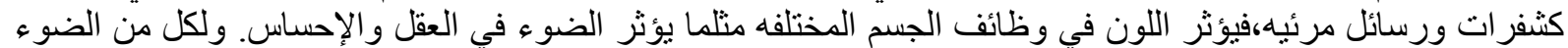

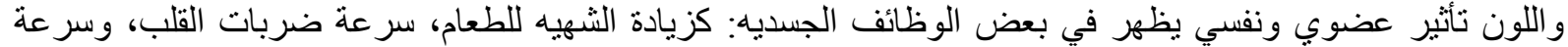
معدل سريان الدورة الامويه.

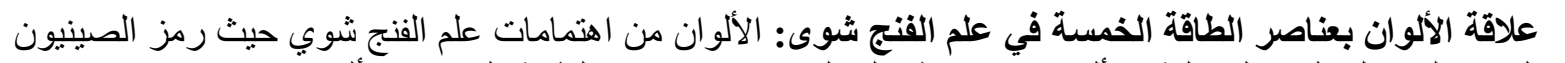

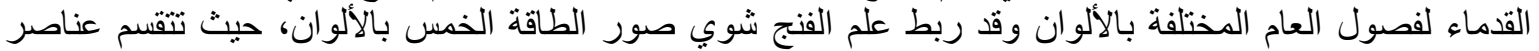

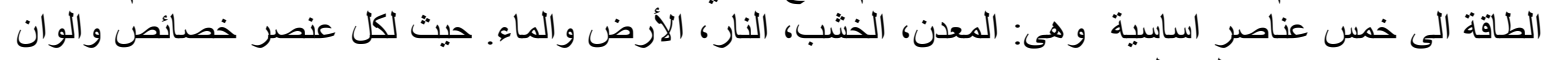
معبره عنه كما موضح بالجدول(r). 


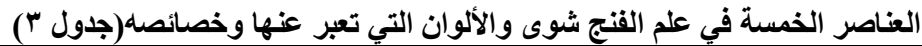

\begin{tabular}{|c|c|c|}
\hline \multicolumn{3}{|c|}{ جدول(r))يوضح الجدول الألو ان الخاصة بكل عنصر من عناصر الطاقة وخصائصه المرجع رقم(r I)(بتصرف الباحث). } \\
\hline خصائص كل عنصر & اللون & عناصر الطاقة \\
\hline يرمز الى النمو والخلق قودورة الحياة & الاخضر & الخشب \\
\hline برمز للحركة و الذكاء و النشاط & الاحمر & 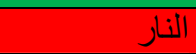 \\
\hline ترمز للثبات و الاشياء المصمتة & الاصفر & الارض اض \\
\hline يرمز للنجاح الاقتصادى و الثروة & الابيض & المعدن \\
\hline ترمز للنقاء و انتقال الافكار & الازرق & الماء \\
\hline
\end{tabular}

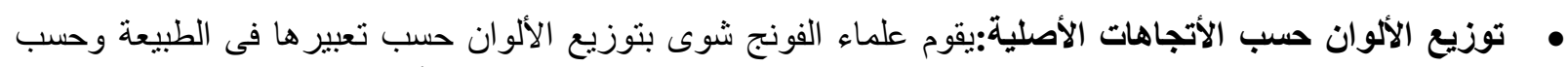

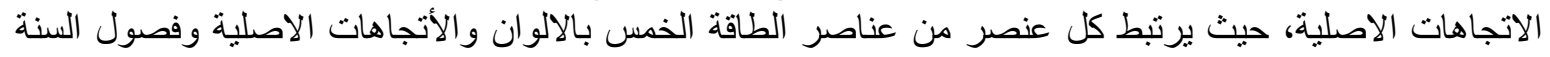

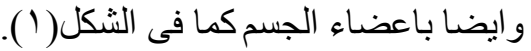

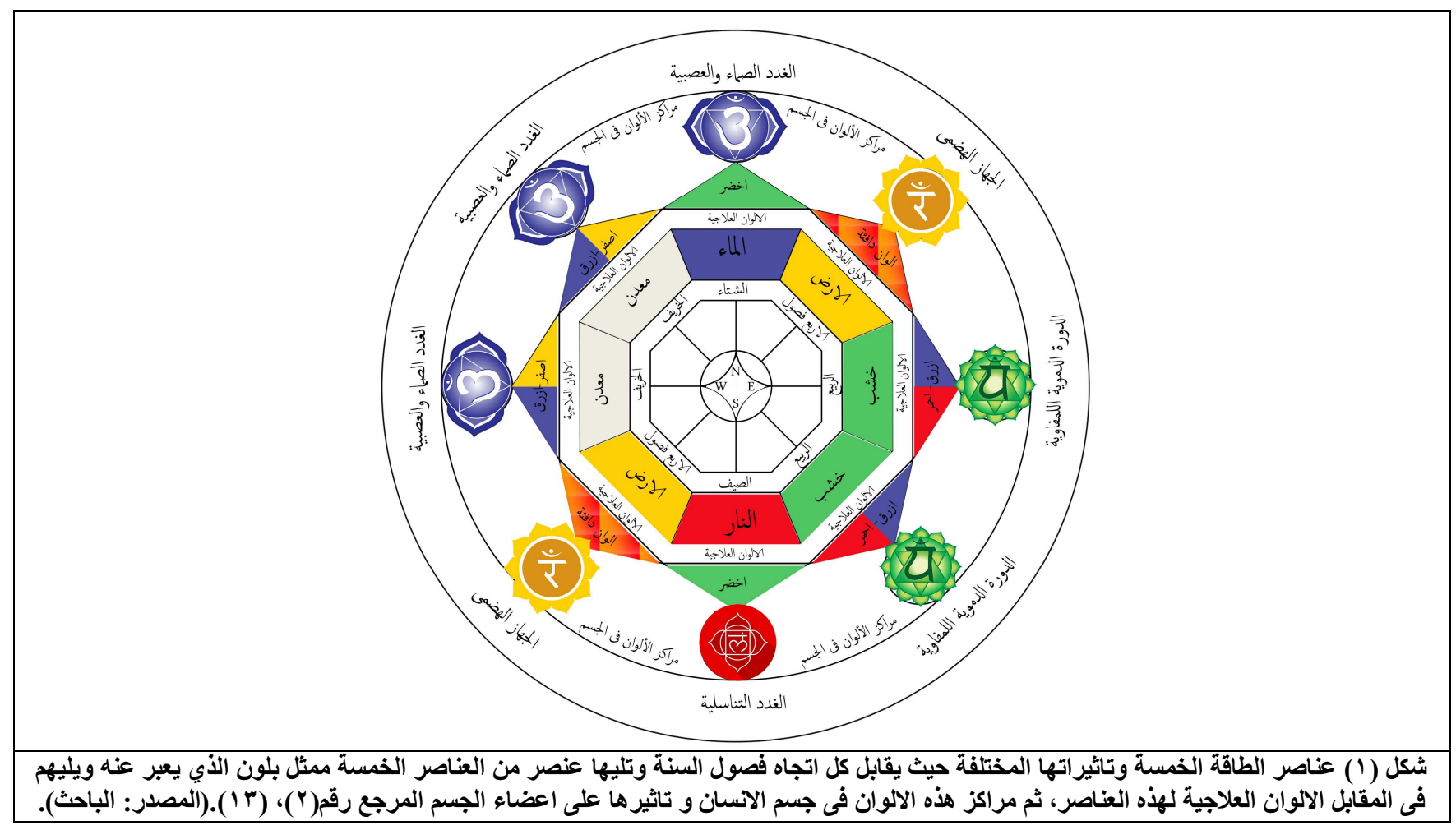

تاثير الالوان على الانسان من مفهوم الطاقة:

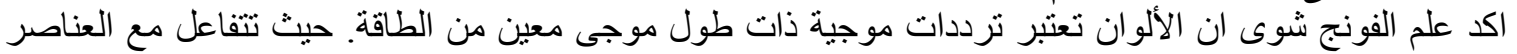

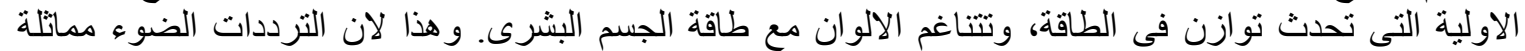

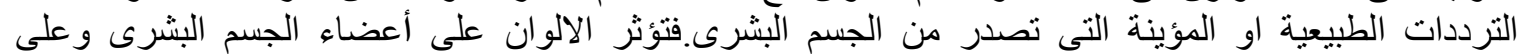
احاسيسه ومشاعره. ومن هذه الطاقة سبع شاكر ات دائرية(7 CHAKRAS) من الطاقة تكمن في سبع نقاط مختلفة

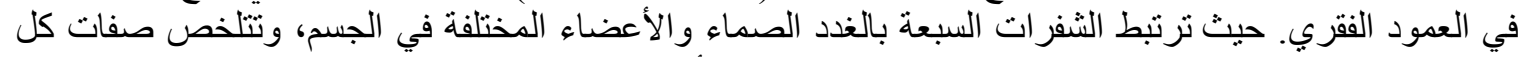
منها فى الجدول(ع).وبالتالي يمكن تعريف الثفرات السبع بأنها:مفهوم نابع من الثقافة الهندية يعبر عن في مراكز

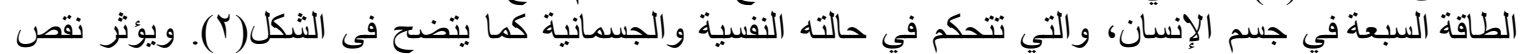
التعرض لعناصر الضوء أو الطيف المرئي الى ظاهرة الاكتئاب والتى تؤثر فسيولوجيا على نفسية الإنسان. 


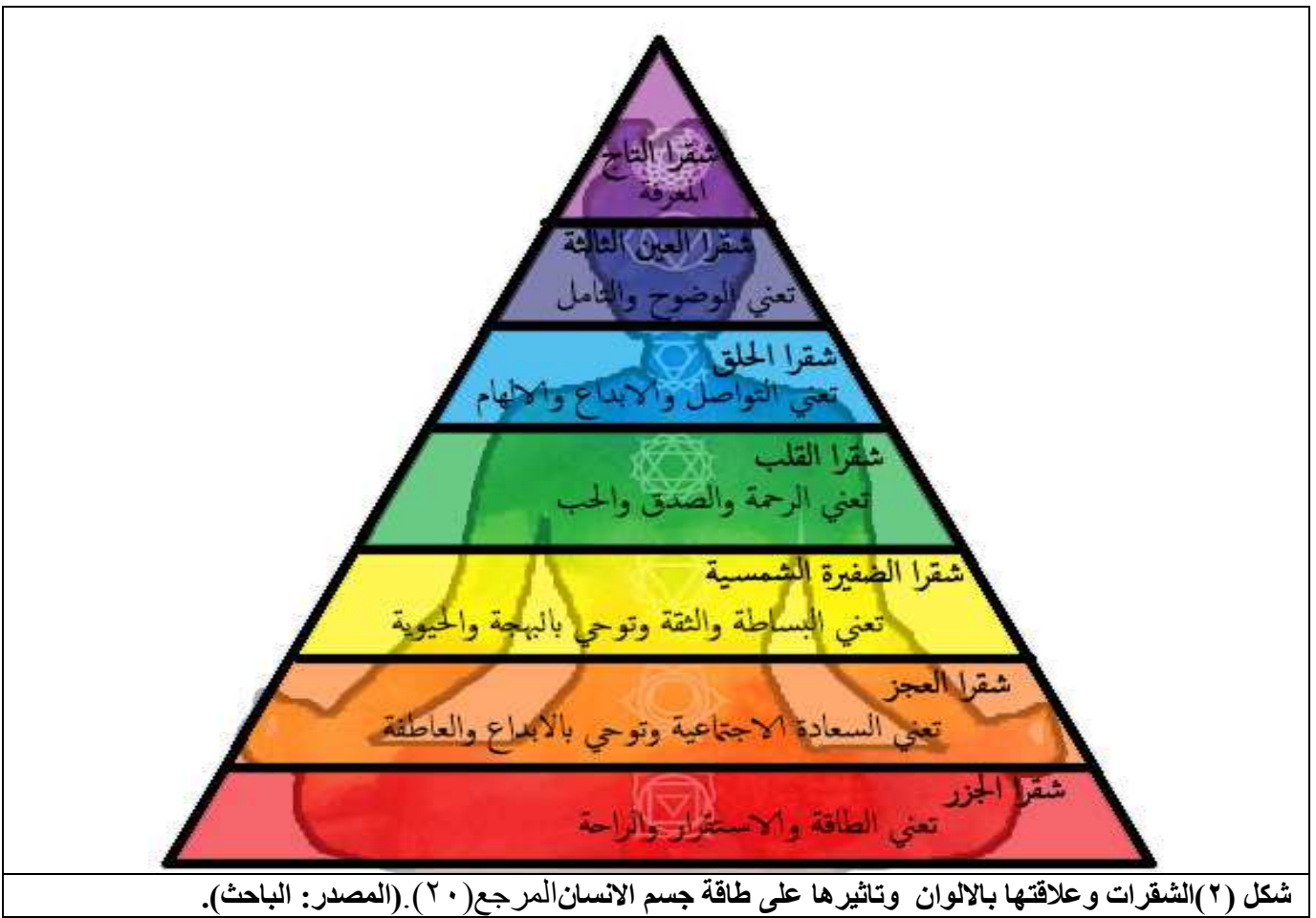

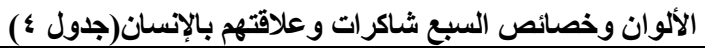

\begin{tabular}{|c|c|c|c|c|}
\hline \multicolumn{5}{|c|}{ 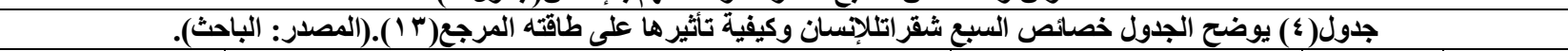 } \\
\hline موقعهافي الجسم & خصائصها & $\begin{array}{r}\text { اسم الشاكرات } \\
\text { (CHAKRAS names) }\end{array}$ & & اللون \\
\hline 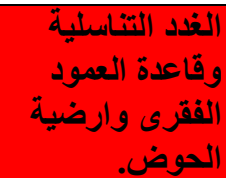 & 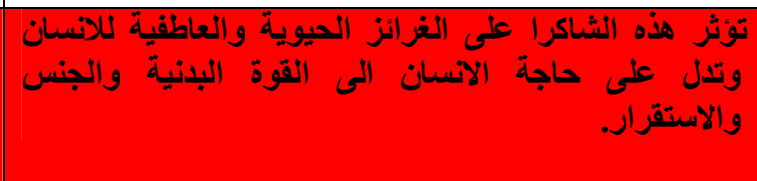 & الماكن شـاكرا الجذز & & الاع \\
\hline والغهد الكظرية البولى & ترحى بالابداع والثهاكرا بالوظائف العاطفية. & شاكرا العجز & & البرتقالى \\
\hline الجهاز الهضمى & ملى الاحولة هذه الشاكر الثقة والبهجة ونجاح الشخصية وتساعد الشخص & $\begin{array}{r}\text { شاكرا الضفيرة الشمسية Chakra } \\
\text { Solar Plexus Char }\end{array}$ & & الأصفز \\
\hline 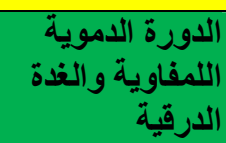 & 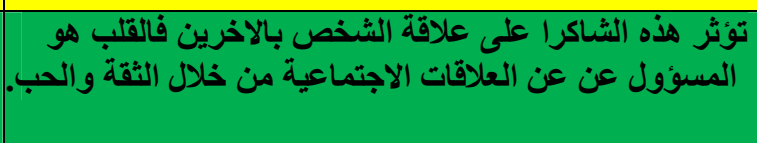 & شاكرا القَب & & الأخضر \\
\hline 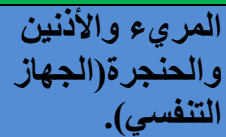 & ترتبط هذه الثاكرا بقدرة الانسان على التواصل & شاكرا الحلق & & النيلى اللون \\
\hline والغديد الصيمائ & 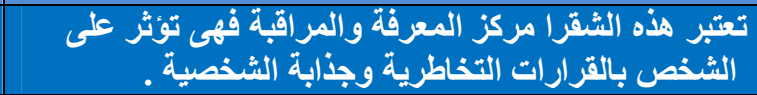 & he Third Eye Chakra & & الأزرق \\
\hline والبهماز العصبة الدماغ & 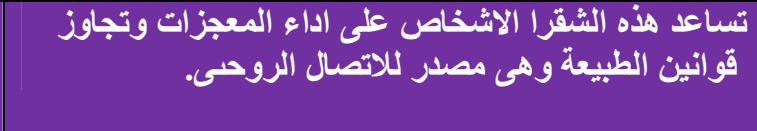 & 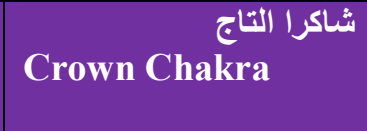 & & : \\
\hline
\end{tabular}

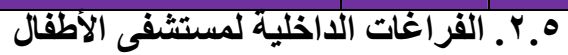

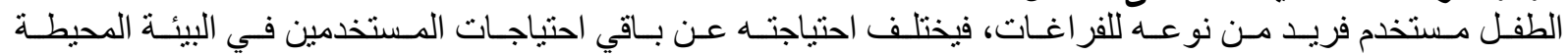

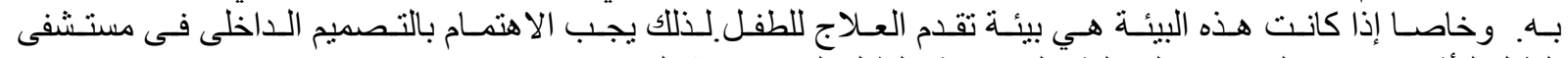

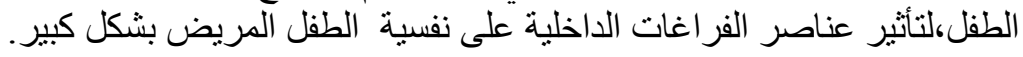




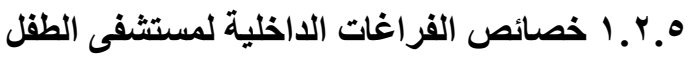

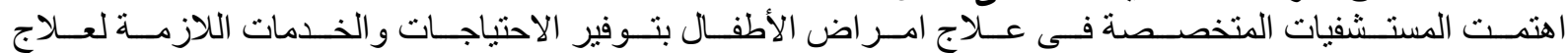

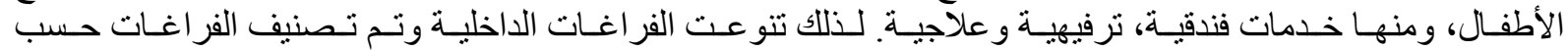

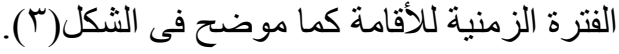

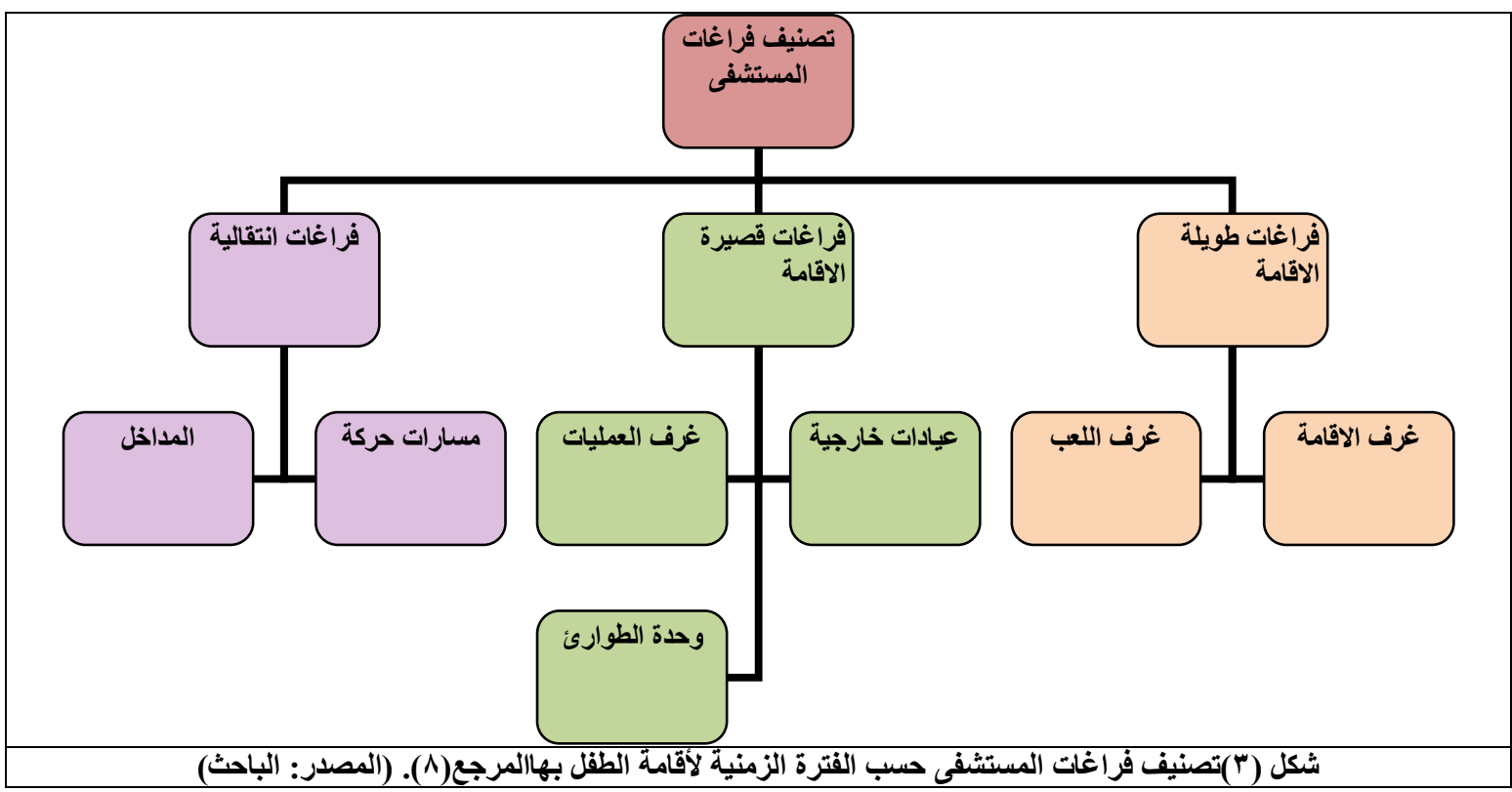

• رف الاقامة:تصمم غرف الاقامة بالمستشفيات لتناسب احتباجات ومنطلبات الطفل الرئيسية من طعام و عناية طبية

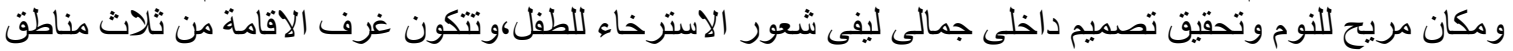

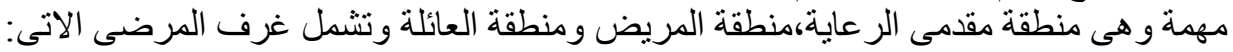

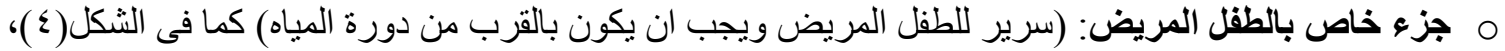

$$
\text { O جزء جزء جاص بالمرافقين: (سرير لاحد المر افقين). }
$$

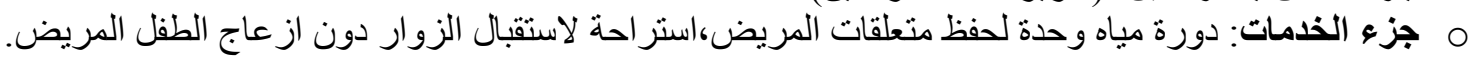

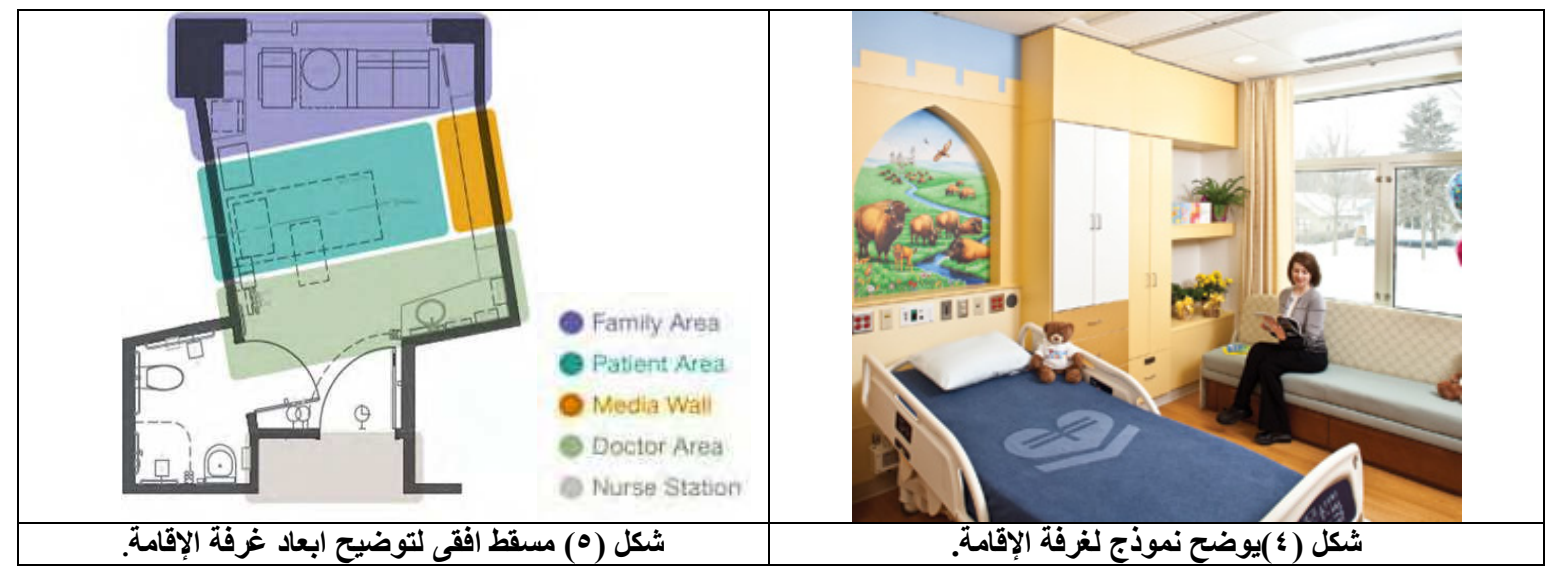

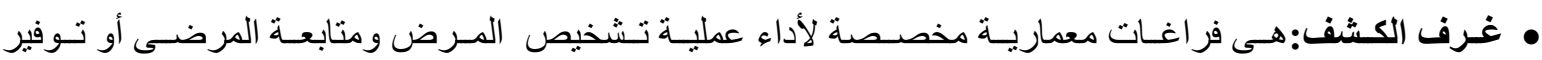

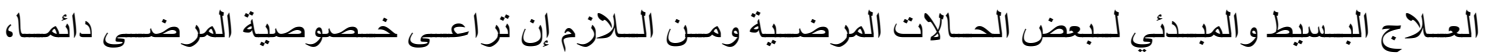

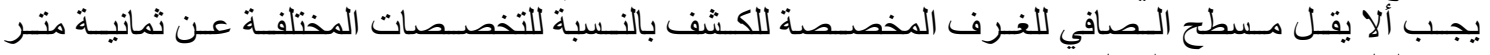

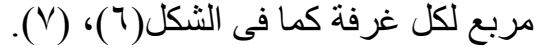




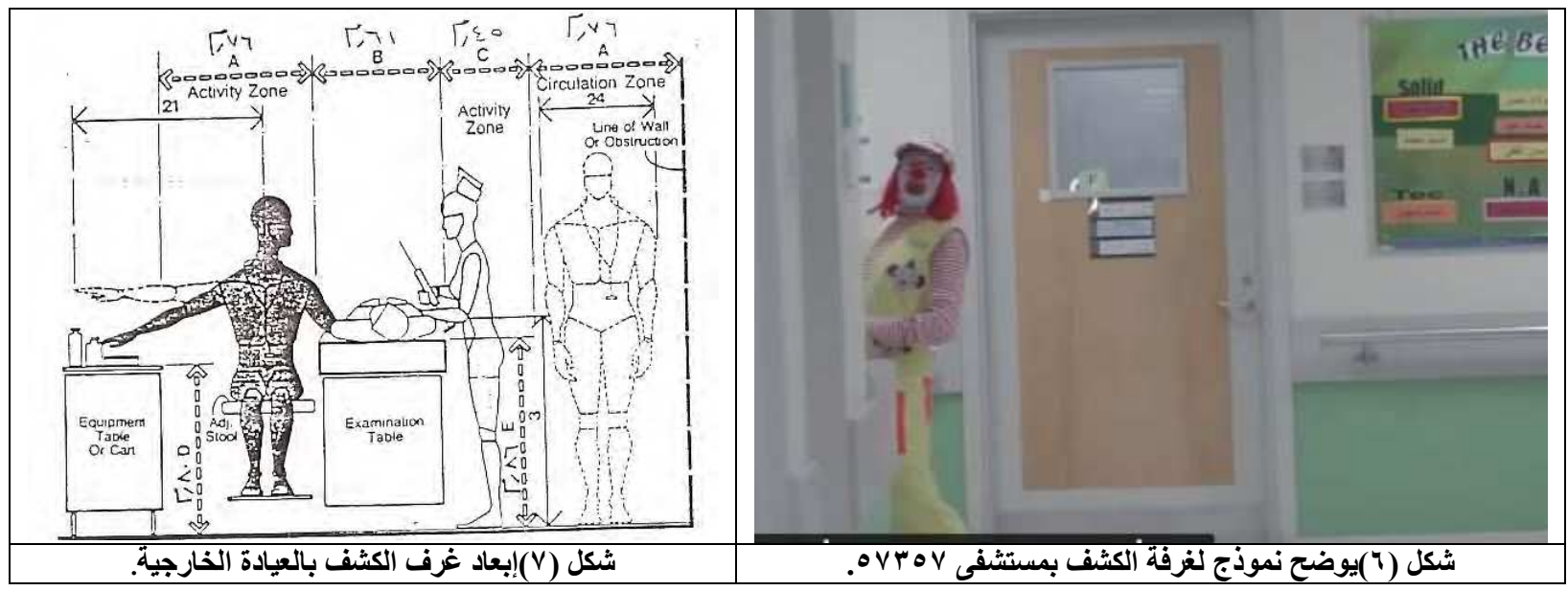

• المداخل: هو فراغ انتقالي يربط الحيز ات يبعضها ويجب ان يكون واضح للأطفال المرضى. ويعتبر بؤرة الرؤية

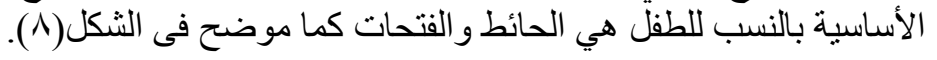

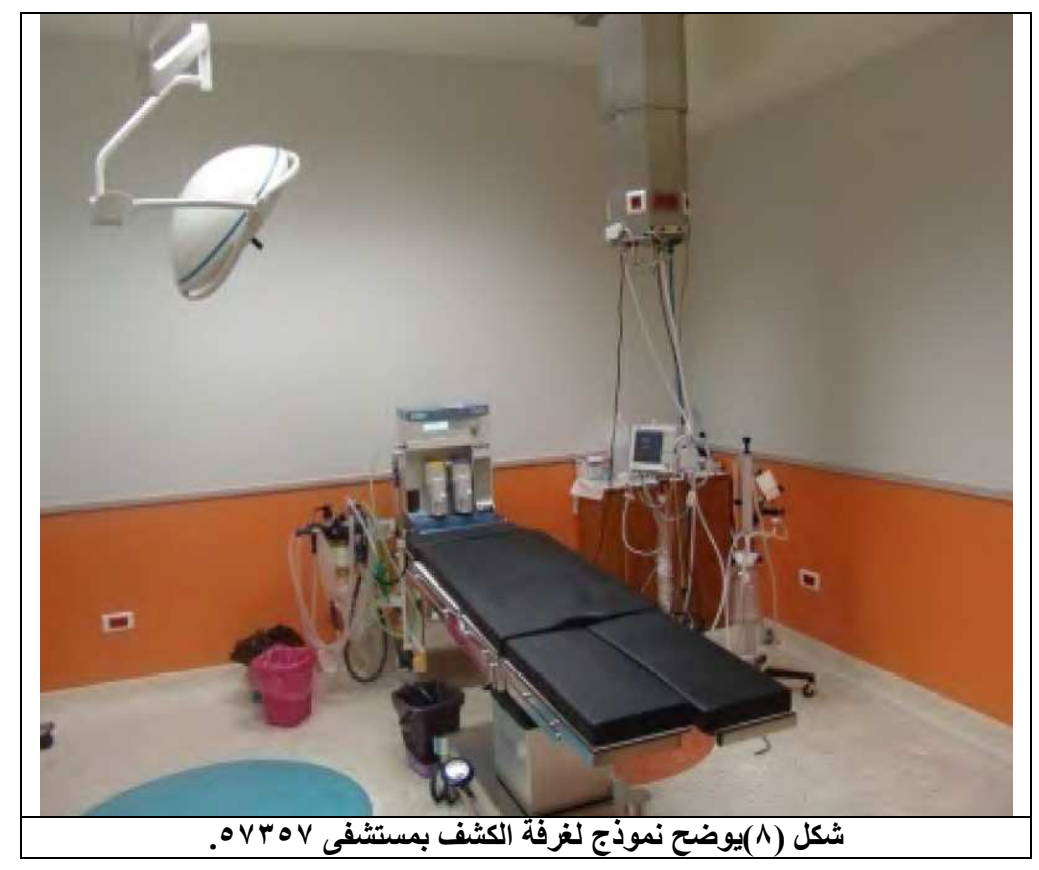

• المسارات:هو فراغ انتقالى للتنقل من فراغ الى اخر. ويجب مر اعاة تحديد المسار للطفل وتجنب استخدام الممرات

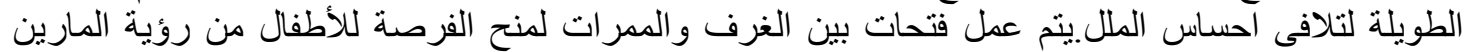

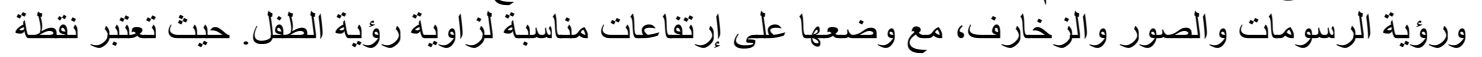

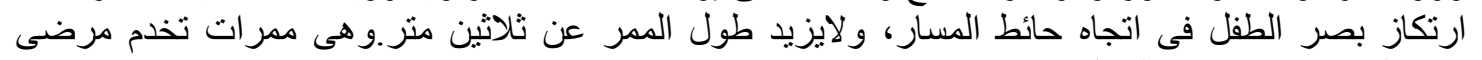
الاطفال كما موضح فى الثكل (9)، (1)، (1). 


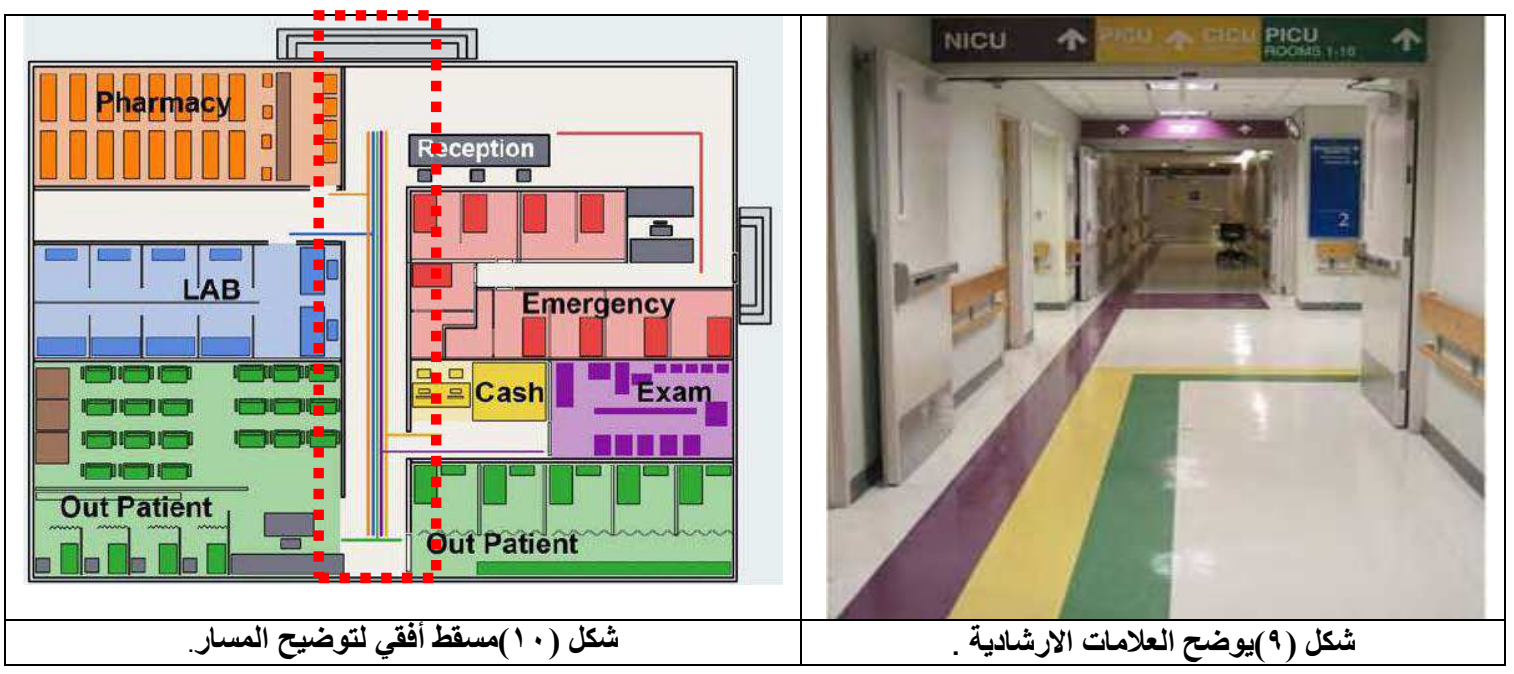

• غرف لعب الاطفال: هو فراغ يقضى الطفل فيه وقت كبير وتوجد هذه الفر اغات على الاقل غرفة فى نهاية كل ممر الحر

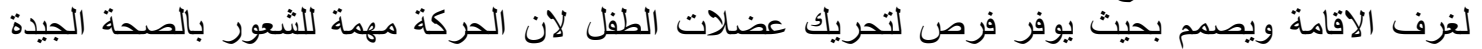

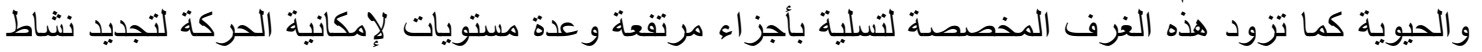

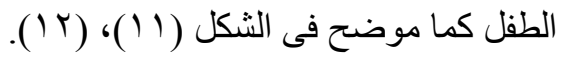

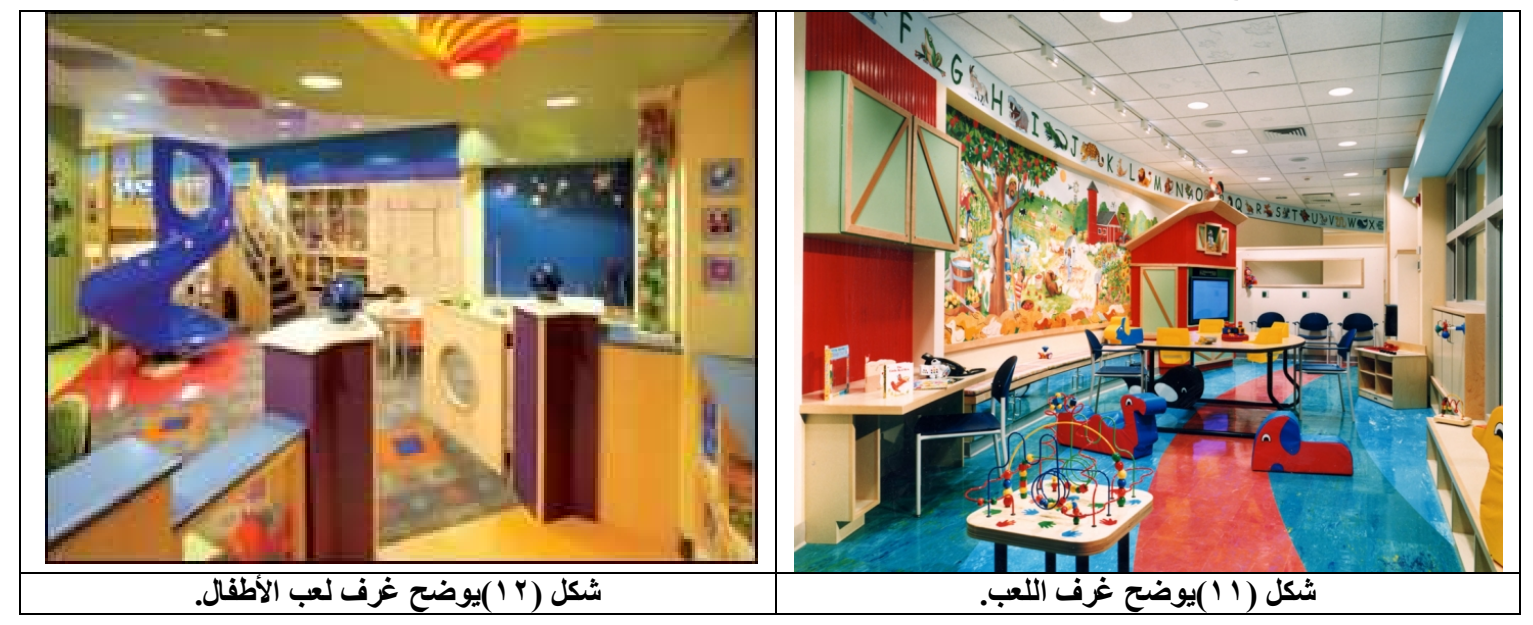

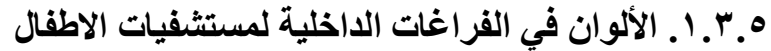

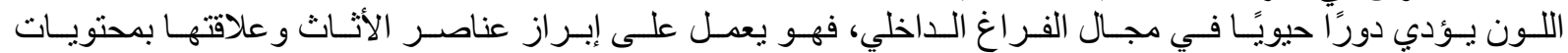

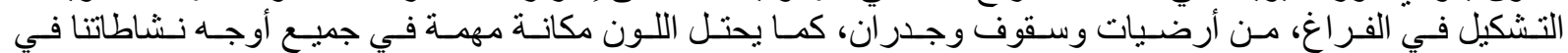

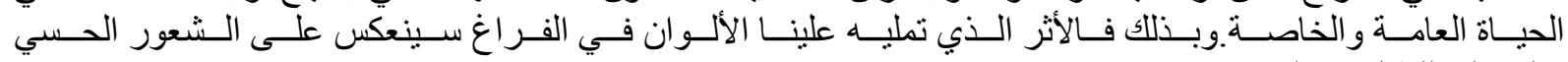

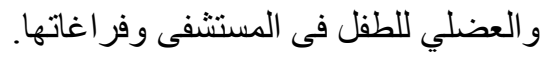

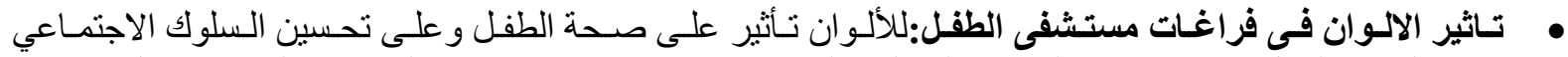

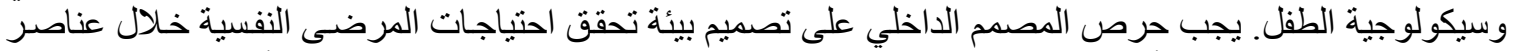

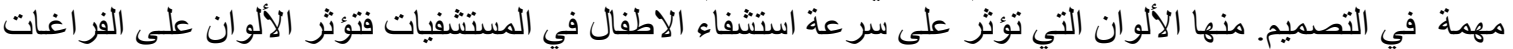

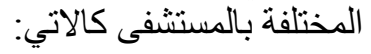

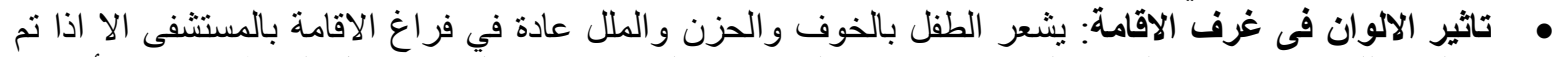

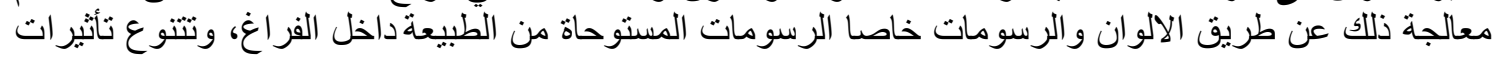

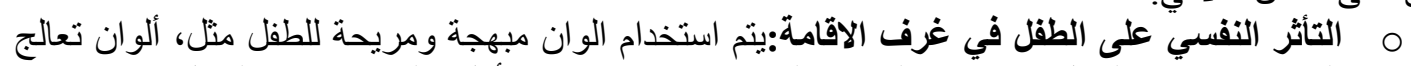

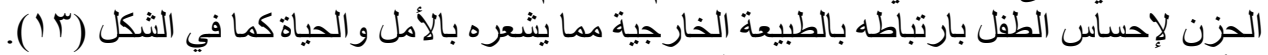

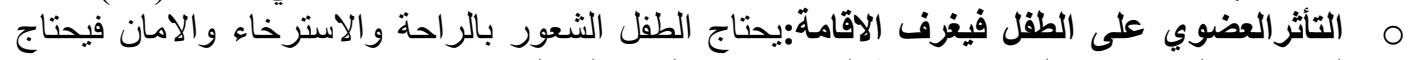
لعناصر و الو ان تهدئ التنفس وضغط فئرف الدم وتساعد على عملية الهضم. 
تأثثير الألوان الأسنشفائية بالفر اغات الداخلية لمستشفى الطفل

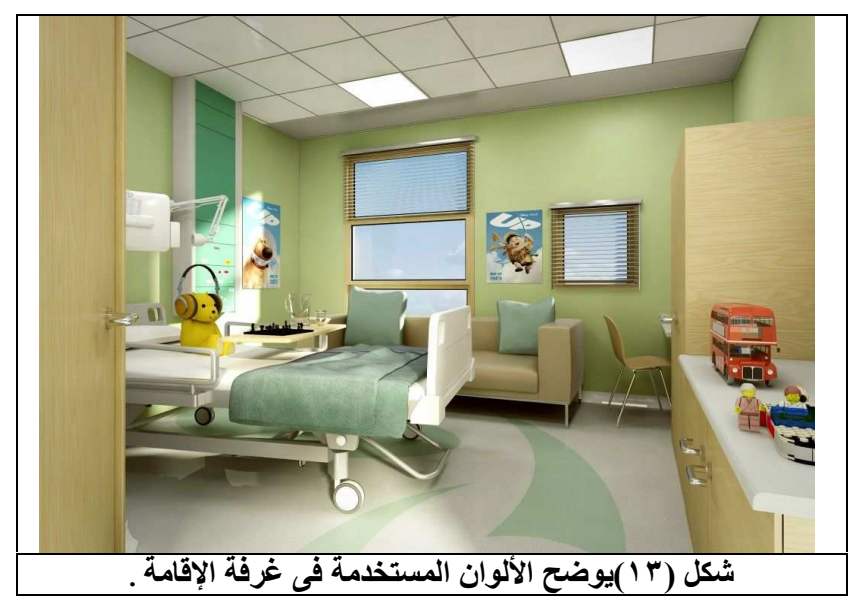

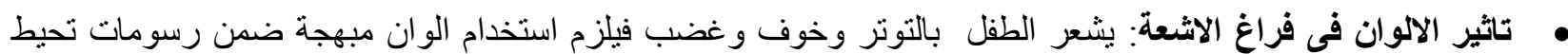

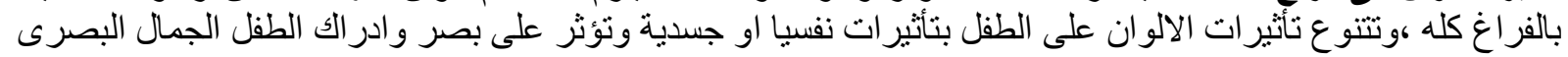

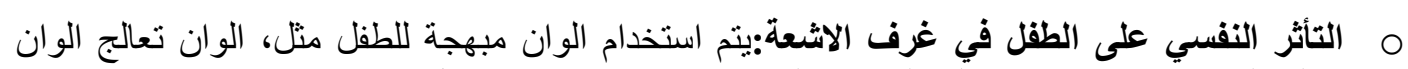

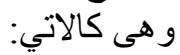

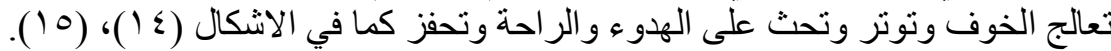

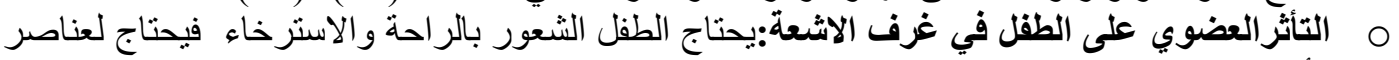

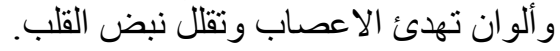

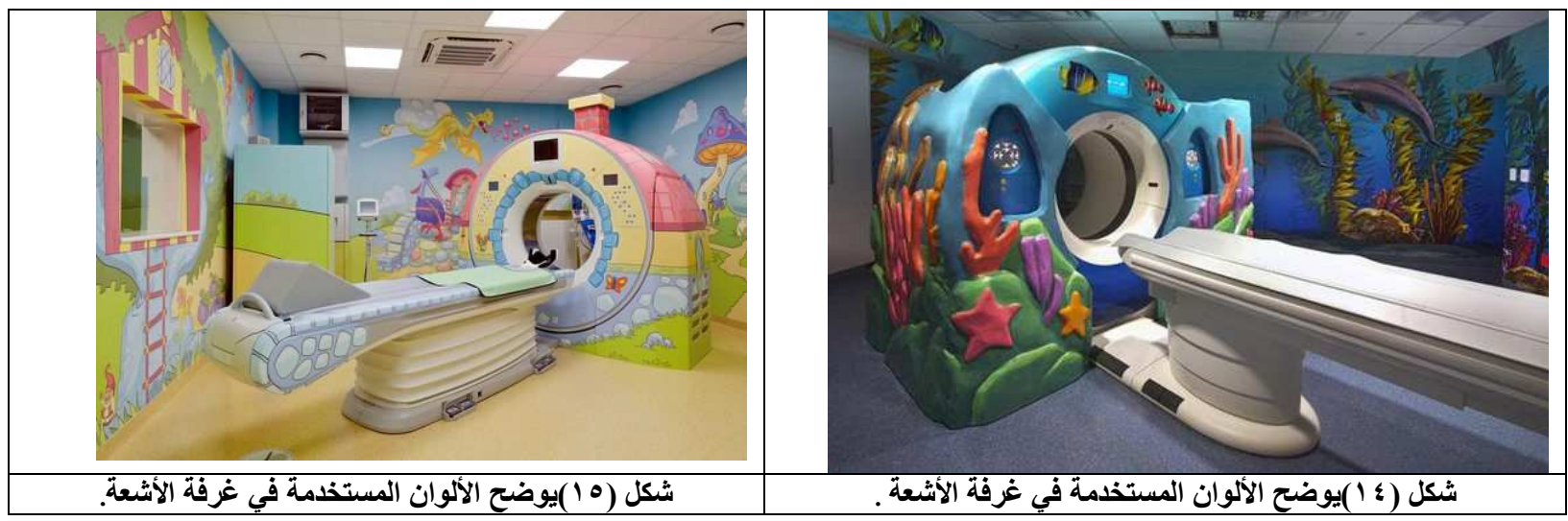

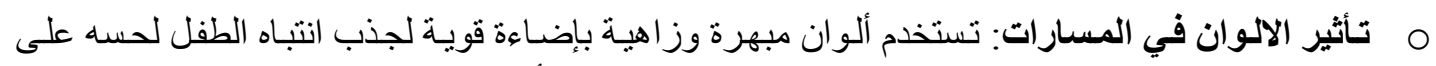

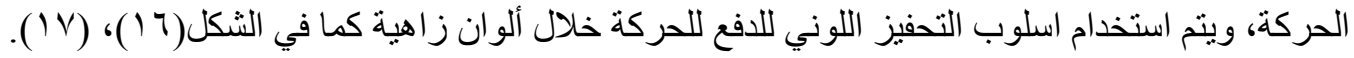

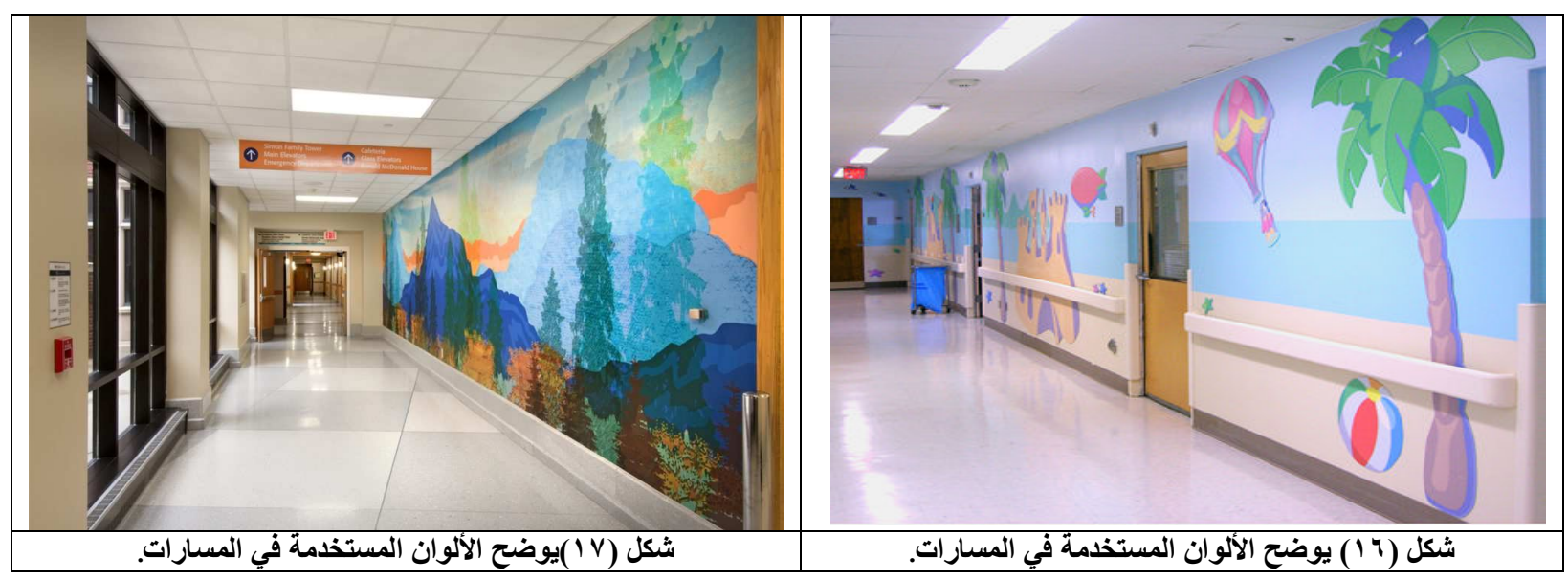


تاثير الالوان فى غرف اللعب: تستخدم الوان دافئة لإقامة انشطة ابداعية مثل اللون الأحمر والأصفر لان هذه الألوان

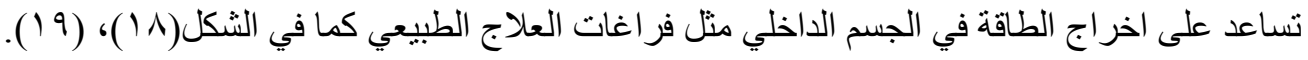

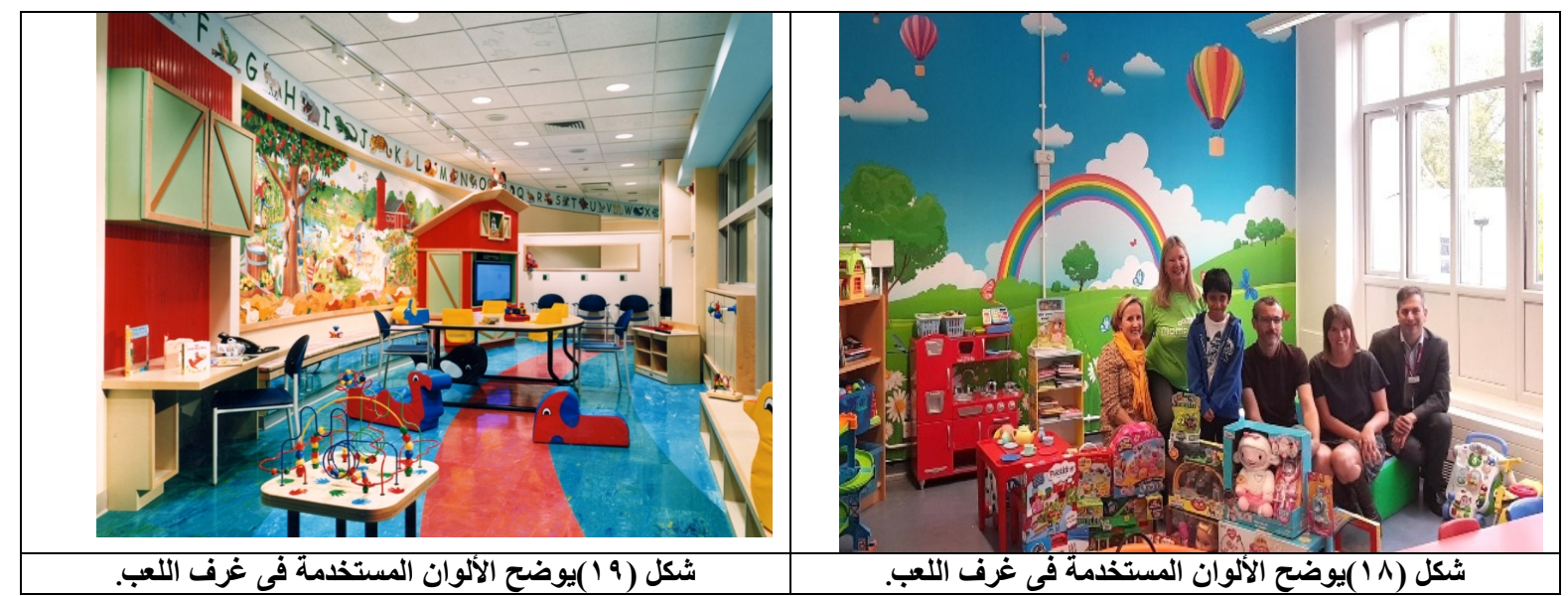

تاثير الالوان فى غرف الكثف:تساعد الألوان الباردة على الهدوء و التركيز في غرف الكشف لأن الطفل يشعر بالتوتر

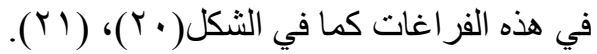

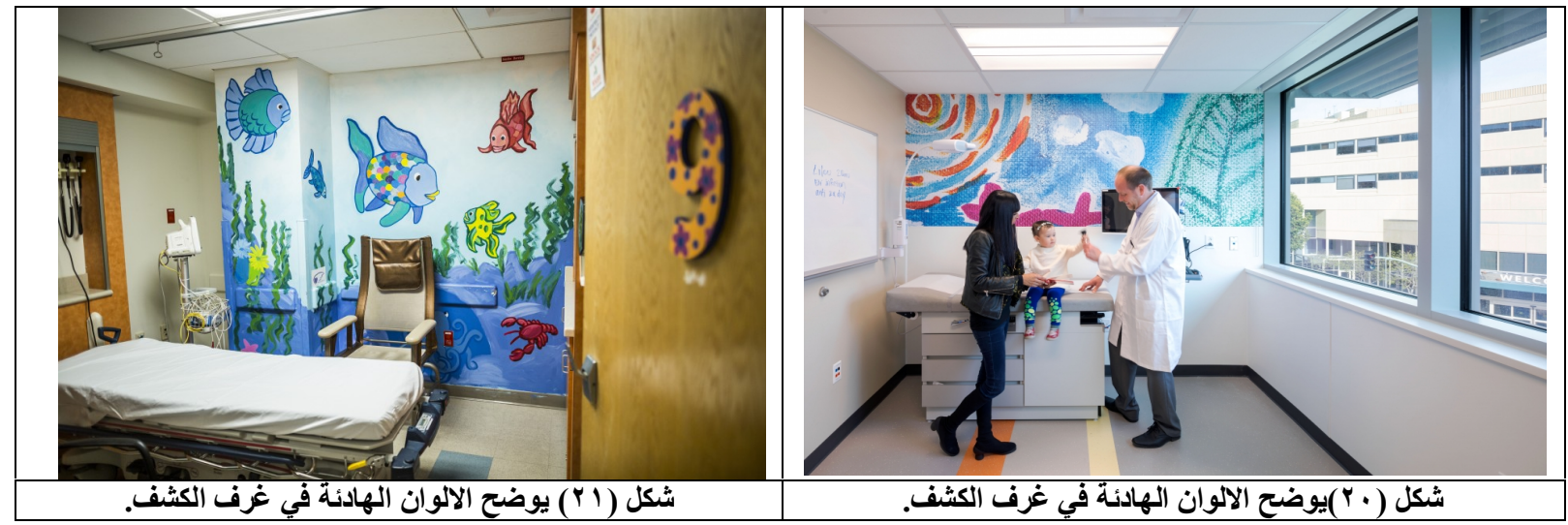

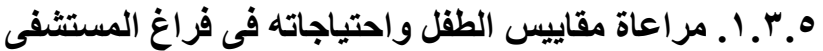

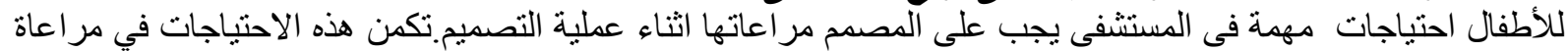

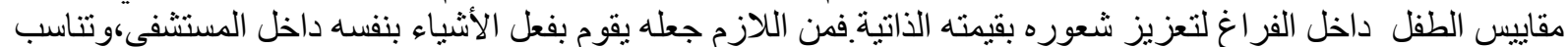

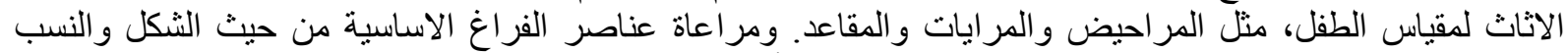

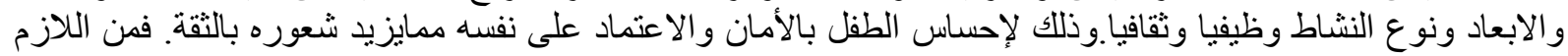

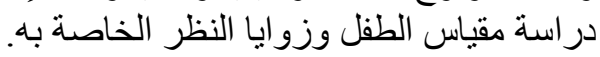

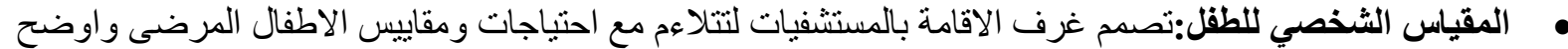

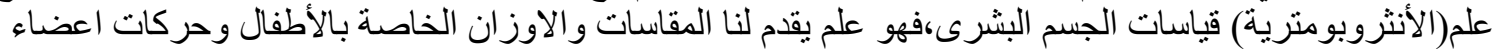

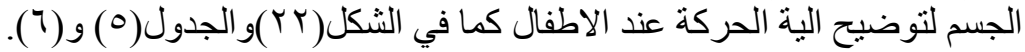



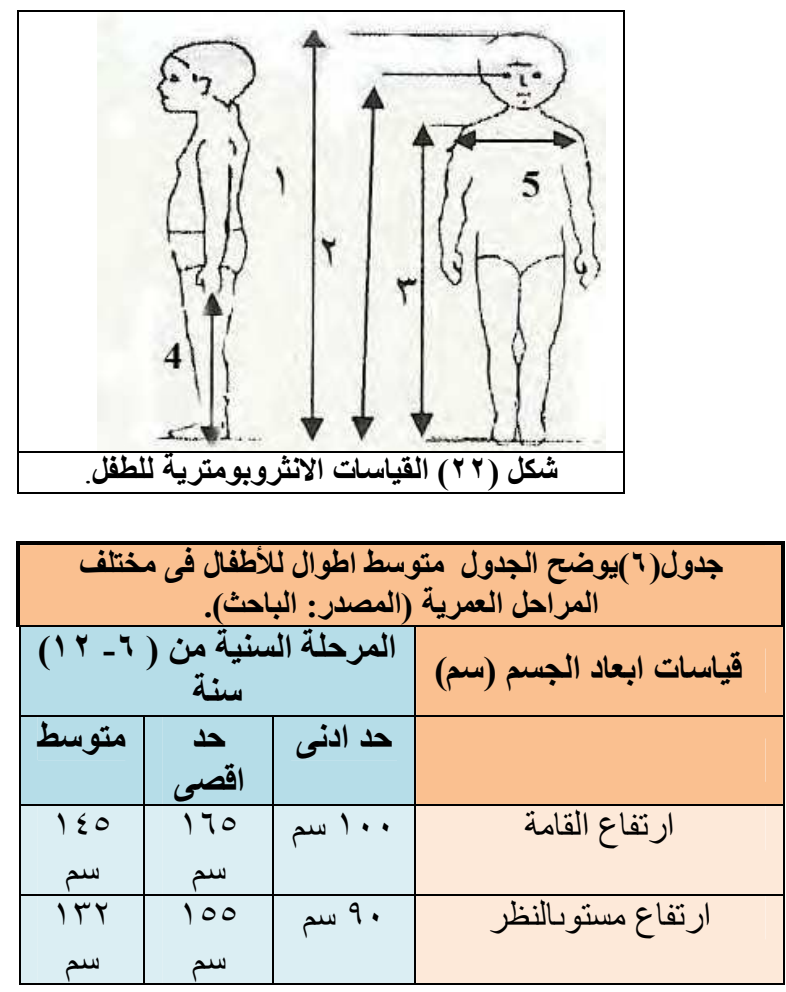

\begin{tabular}{|c|c|c|c|}
\hline \multicolumn{4}{|c|}{ جدول(0) يوضح القياسات الانثرويومتريةٌ للطقل المصرى. } \\
\hline اربتقاع مستوى التطر (ץ) & طول القامة & & \\
\hline V.. & Ao & 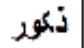 & \multirow[t]{2}{*}{ سنتين } \\
\hline vo. 1 & A $\leqslant . Y_{0}$ & | إثاث & \\
\hline$\wedge \varepsilon . \leqslant$ & atr.vo & ذكمرف & \multirow[t]{2}{*}{ r سنوات } \\
\hline 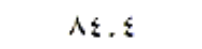 & FT. vo & | إثاث & \\
\hline Aᄉ & จั.А. & ذ ذكور & \multirow[t]{2}{*}{ أسنوات } \\
\hline 人ร. ใ & 习T.7. & | إناث & \\
\hline qv. १ & l.v. & ذفمور & \multirow[t]{2}{*}{ ه سنوات } \\
\hline 97.9 & $1.7 . \wedge$. & إناث & \\
\hline 99.7 & $1 \cdot \cdot v$. & ذبمور & \multirow[t]{2}{*}{ 7 سنوات } \\
\hline $9 \wedge . \wedge$ & 1.1. & إناث & \\
\hline
\end{tabular}

o أطوال الأطفال في مختلف الفئات العمرية:

يختلف طول طفل عن الاخر حسب العمر و هى تتنوع كما موضح في الجدول (V) وشكل(rY).

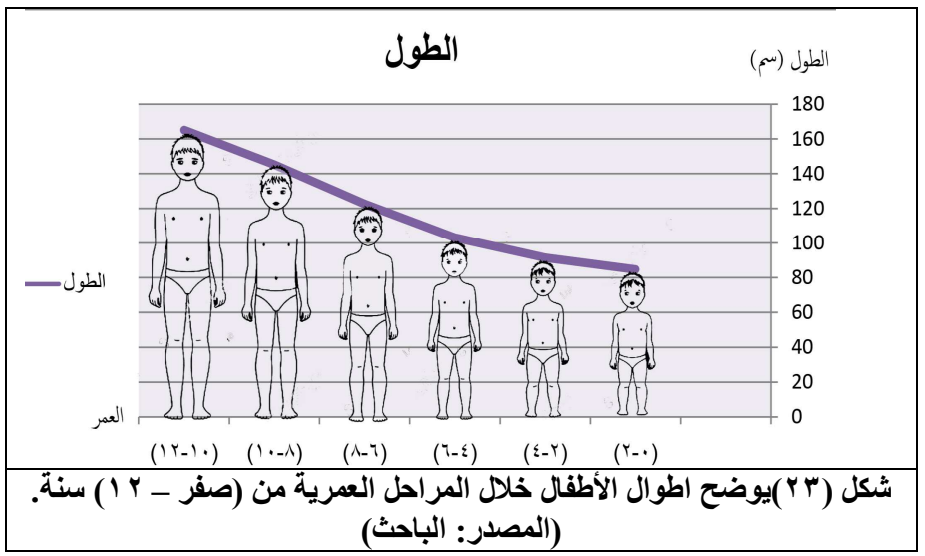

\begin{tabular}{|c|c|c|}
\hline \multicolumn{3}{|c|}{ مختلف المر احل العمرية. (المدول منوسط أطو ال للأطفال فى الباحث) } \\
\hline ارتفاع مستوى النظر & بتوسط طول & العمر بالسنة \\
\hline$V 7,10$ & $\Lambda \varepsilon, 7 T$ & من صفر - r 1 ا \\
\hline AT, To & 91,17 & من r \\
\hline $9 \varepsilon, 71$ & $1 \cdot r, 91$ & من ع - 7 \\
\hline 111 & ITY,O. & من 7 - 1 \\
\hline IMr & $1 \leqslant 0$ & من 1 - 1 \\
\hline 100 & 170 & من · _ \\
\hline
\end{tabular}

م زوايا روئية الأطفال

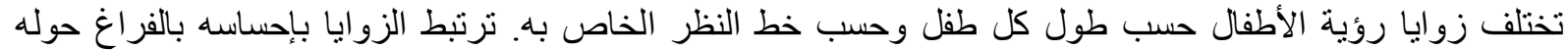

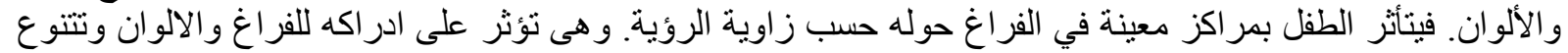

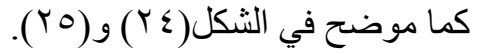



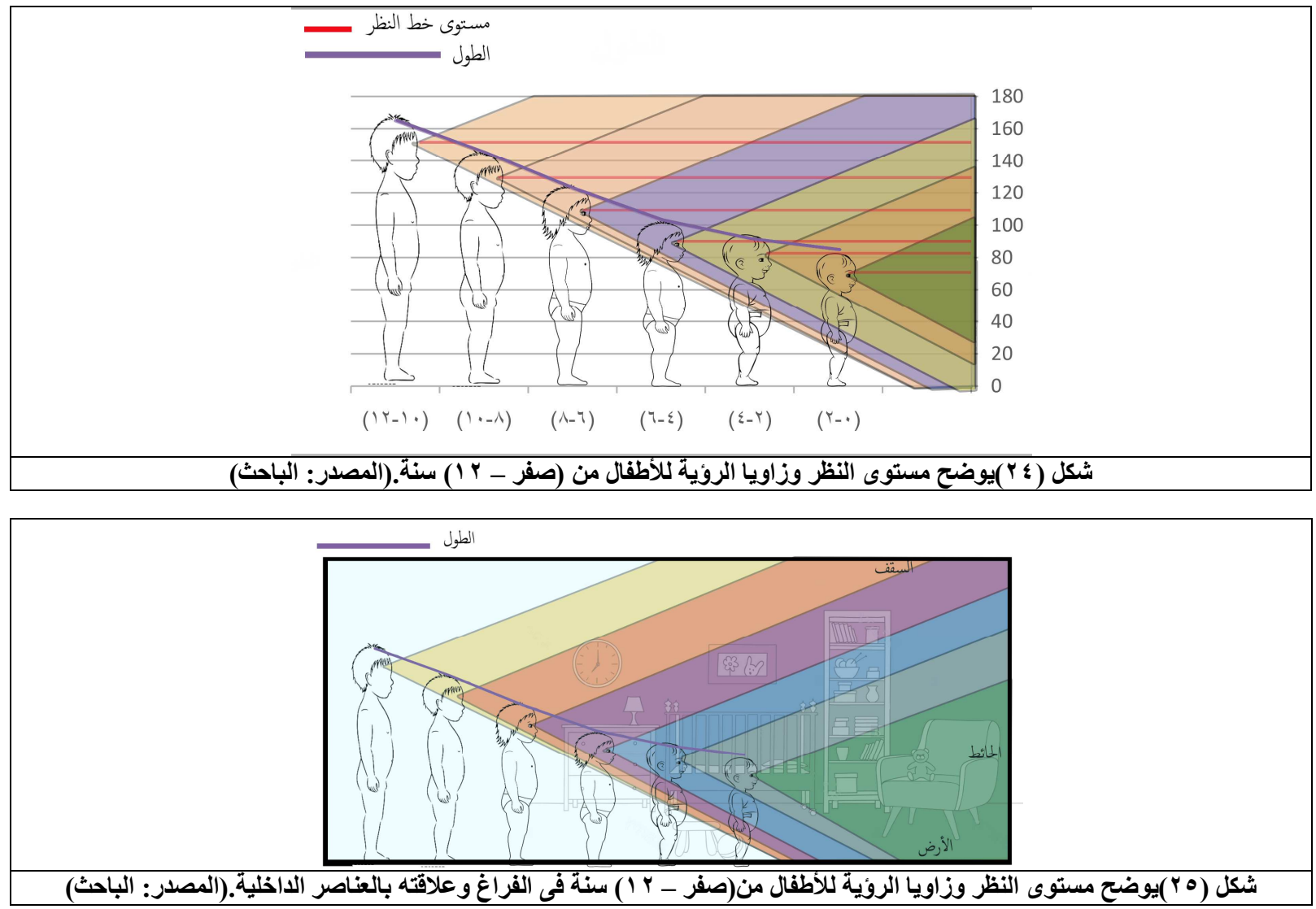

T.الاراسة التطبيقية

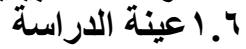

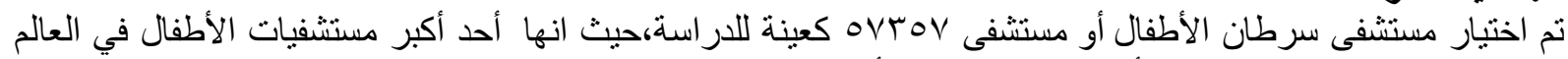

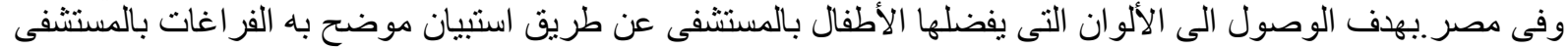
بالوان مختلفة .

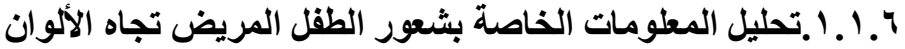

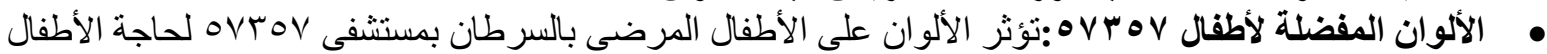

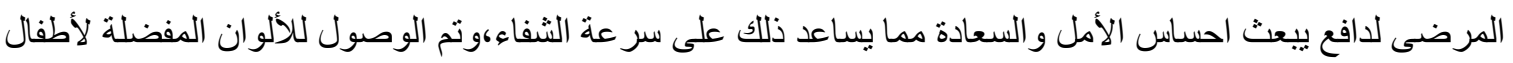

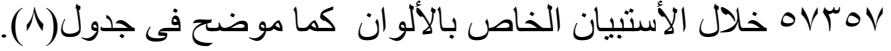

\begin{tabular}{|c|c|c|c|c|}
\hline \multicolumn{5}{|c|}{ جدول(^) يوضح الجاول الألوان المفضلة للأطفال المرضى بالسرطان (المصدر: الباحث). } \\
\hline \multicolumn{4}{|c|}{ أراء الطقل حول اللون(ايجابية) } & \multirow{3}{*}{ اللون } \\
\hline \multicolumn{4}{|c|}{ الاعمار } & \\
\hline$(1 Y-9)$ & $(9-7)$ & $\left(0^{-1}\right)$ & 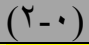 & \\
\hline & & & & اصفز \\
\hline & & & & احمر \\
\hline & & & & برتقالي \\
\hline & & & & ازرق \\
\hline & & & & اخضر \\
\hline & & & & بنفسجي \\
\hline & & & & ابيض \\
\hline & & & & اسود \\
\hline
\end{tabular}




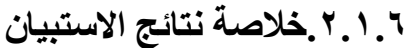

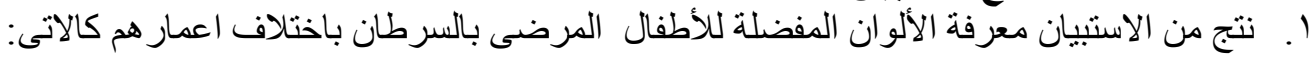

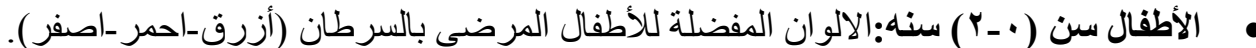

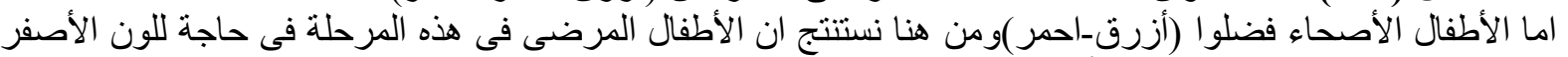

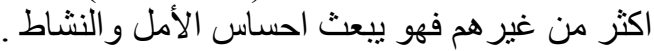

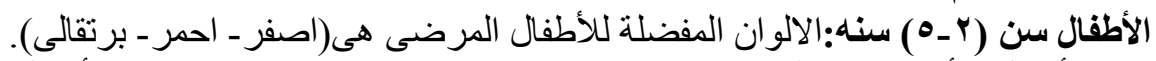

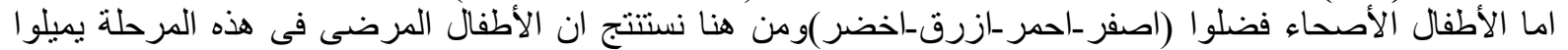

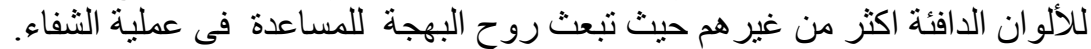
الأطفال سن (7-9) سنه:نتيجة للاستيبان فنجد ان الاطفال المرضى يميلوا الى الألوان (احمر - اصفر -ازرق ـاخضر-

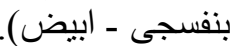

اما الأطفال الأصحاء فضلوا (اصفر ـاحمر -برتقالى_اخضر ) ومن هنا نستنتج ان الأطفال المرضى فى هذه المرحلة يميلو ا

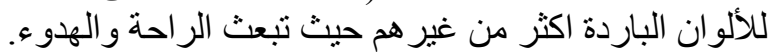

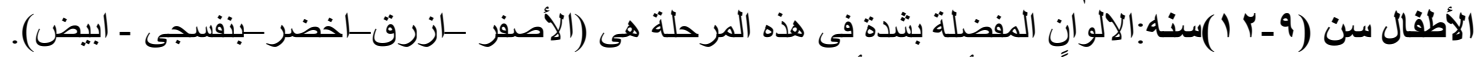

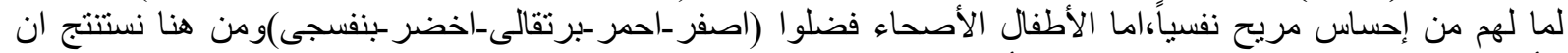

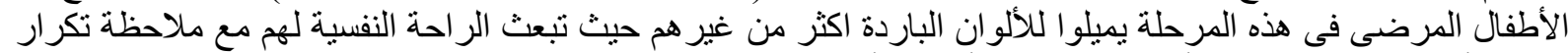

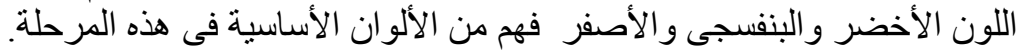

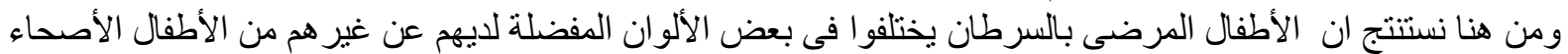

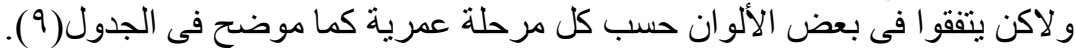

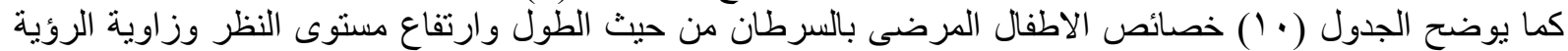

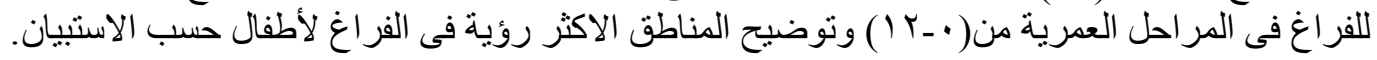

\begin{tabular}{|c|c|c|c|c|c|c|c|c|c|}
\hline \multicolumn{10}{|c|}{ جدول(9) يوضح الجدول مقارنة بين الألوان المفضلة للأطفال الأصحاء والأطفال المرضى بالسرطان (المصدر: الباحث). } \\
\hline \multirow{2}{*}{\multicolumn{4}{|c|}{ الألوان المفضلة للأطفال المرضى بالسرطان }} & \multirow{3}{*}{ اللون } & \multirow{2}{*}{\multicolumn{4}{|c|}{ الألوان المفضلة للأطفال الأصحاء }} & \multirow{3}{*}{ اللون } \\
\hline & & & & & & & & & \\
\hline \multirow[t]{9}{*}{$(1 Y-9)$} & $(9-7)$ & $\left(0^{-}+r\right)$ & $\left(T_{-\cdot} \cdot\right)$ & & $\left(1 T_{-}^{-9}\right)$ & $(9-7)$ & $\left(O^{-1}\right)$ & $\left(T_{-} \cdot \cdot\right)$ & \\
\hline & & & & اصفر & & & & & اصفر \\
\hline & & & & احمر & & & & & احمر \\
\hline & & & & برتقالى & & & & & برتقالى \\
\hline & & & & ازرق & & & & & ازرق \\
\hline & & & & اخضر & & & & & اخضر \\
\hline & & & & بنفسجي & & & & & بنفسجي \\
\hline & & & & ابيض & & & & & ابيض \\
\hline & & & & اسود & & & & & اسوة \\
\hline
\end{tabular}




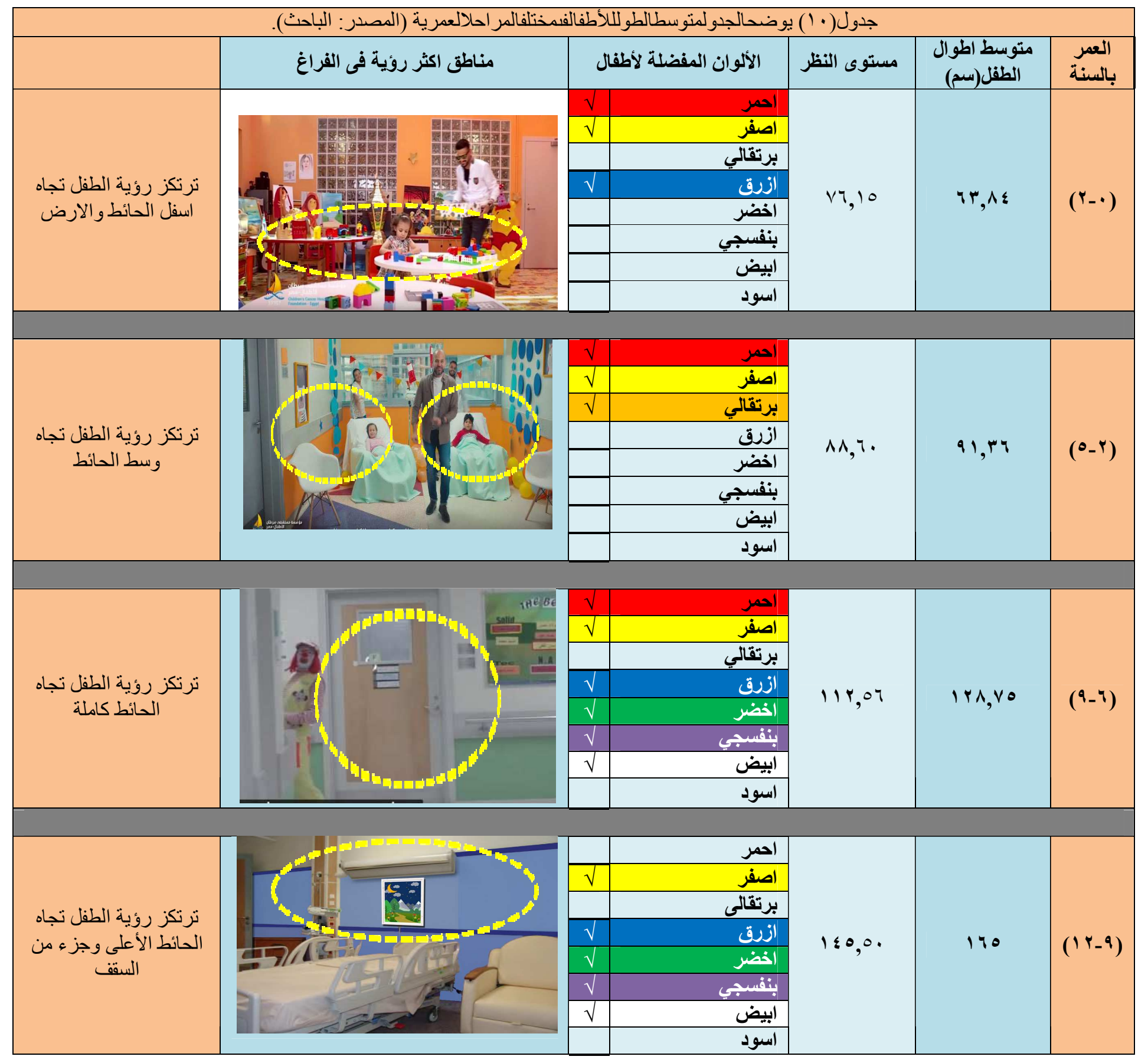




\begin{tabular}{|c|c|}
\hline \multicolumn{2}{|c|}{ 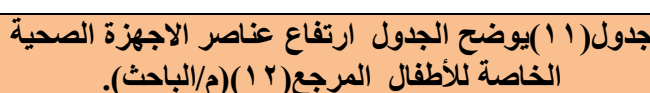 } \\
\hline (سم) & ارتفاع ومقياس عناصر الصحي \\
\hline ะ.q)-r.ی1 & $\mathrm{H}$ \\
\hline r.IVo & I \\
\hline$\varepsilon \cdot .7-\leqslant 0 . V$ & $\mathrm{~J}$ \\
\hline Tr_Al.r & $\mathrm{K}$ \\
\hline 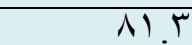 & $\mathrm{L}$ \\
\hline $0 \cdot \Lambda_{-}+\overline{71}$ & $\mathrm{M}$ \\
\hline TrI.9 & $\mathrm{A}$ \\
\hline$V 7 . Y$ & $\bar{B}$ \\
\hline$\{\Lambda, \Gamma-7\}$ & $\mathrm{C}$ \\
\hline $7 \wedge .7$ & $\mathrm{D}$ \\
\hline$\leqslant 0 . V$ & $\mathrm{E}$ \\
\hline $9 \varepsilon$ & $\mathrm{F}$ \\
\hline TAr.9 & $\mathrm{G}$ \\
\hline
\end{tabular}

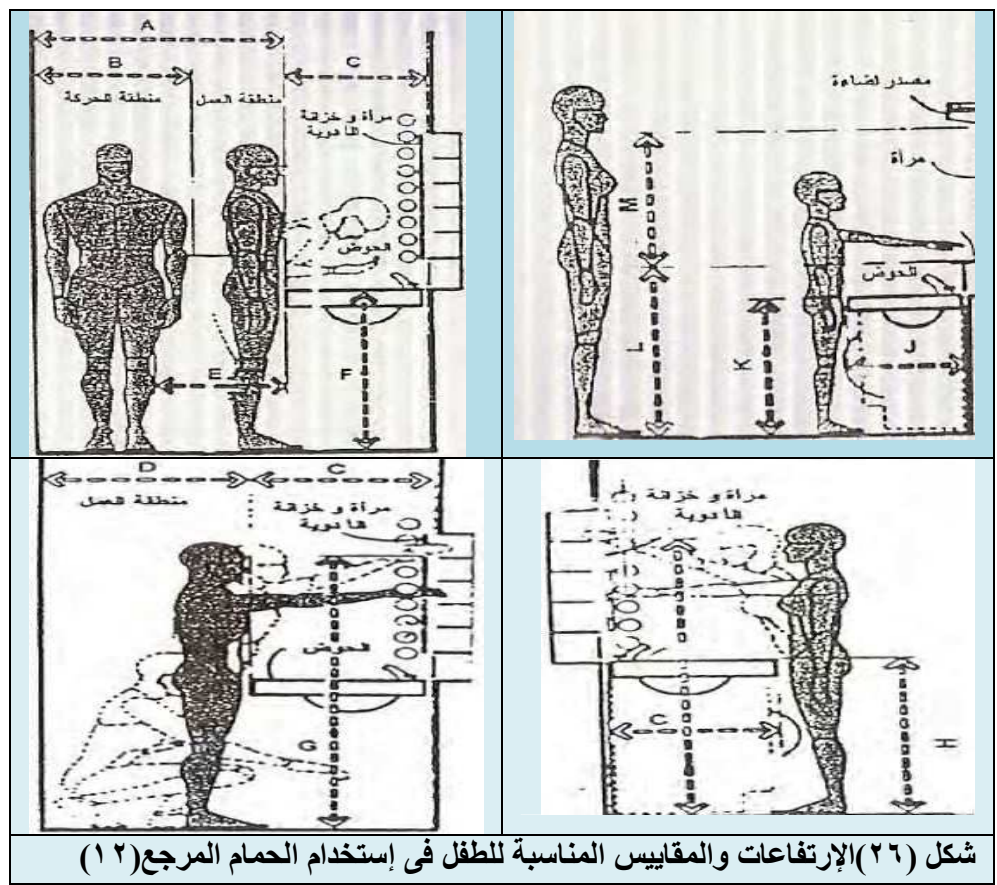

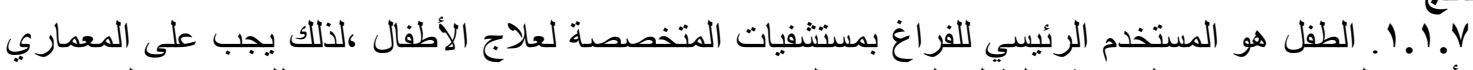

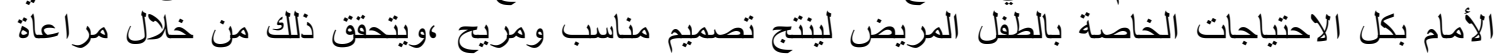

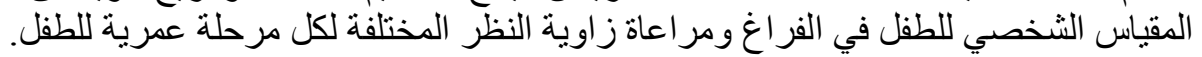

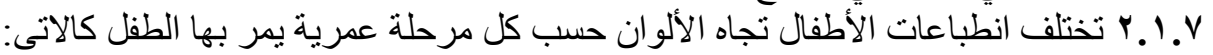

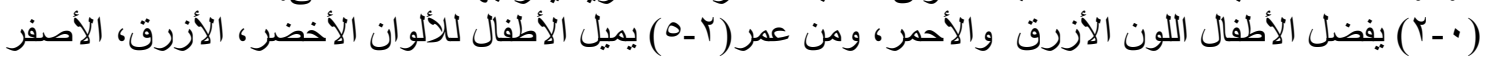

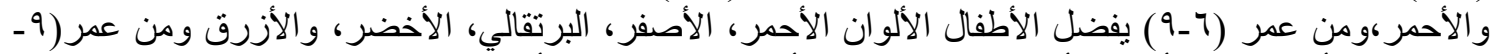

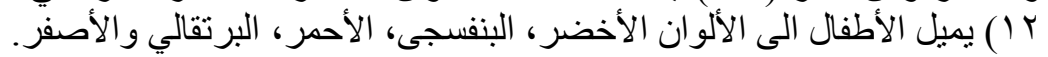

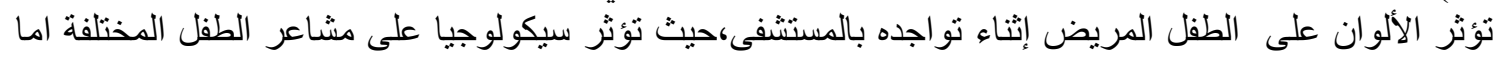

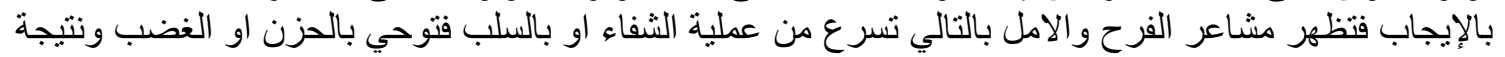
لذللك تؤخر عملية الثفاء. تؤثر الألوان فسيولوجيا على وظائف أعضاء الجسم وايضسا تؤثر على سلوك الطفل الأجتماعى وتو اصله مع الآخرين. 


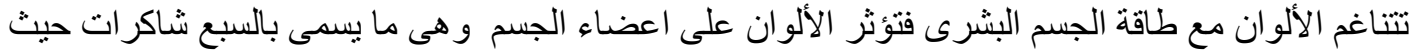

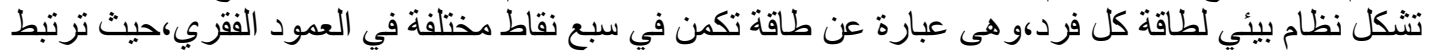

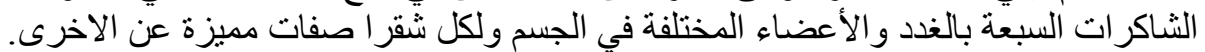

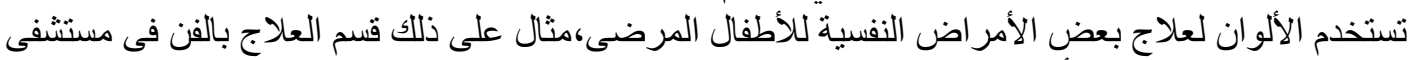

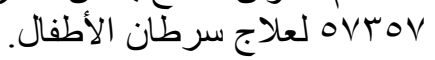

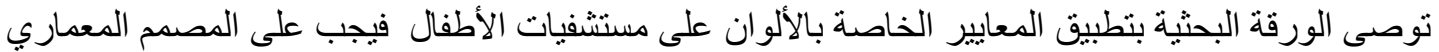

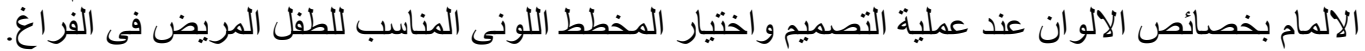

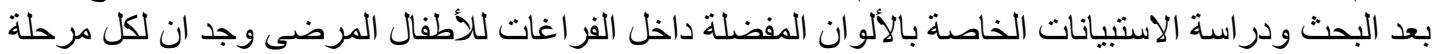

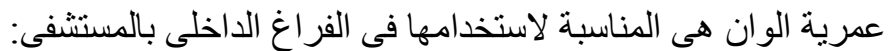

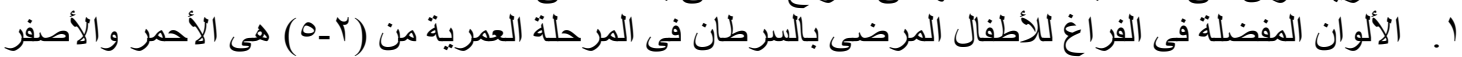

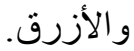

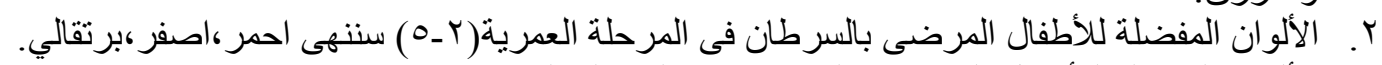

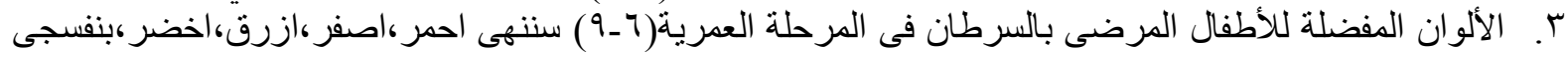

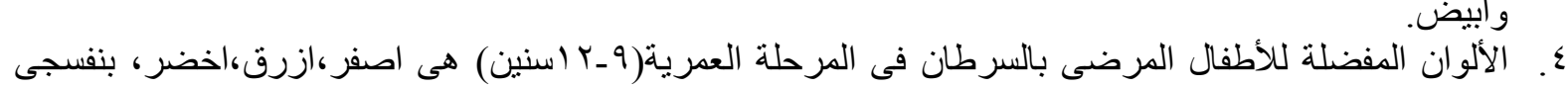
و و ابيضي البحث بضرورة الالهتمام بعلم الالوان وخصائصها فى العمارة الداخلية وزيادة وعى المعماري تجاه اختبار الالوان فى الفر اغات الداخلية.

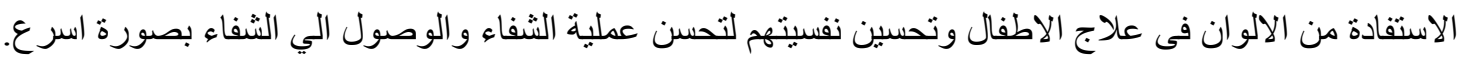

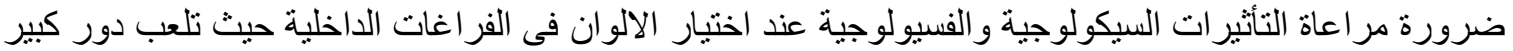

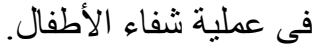
يوصي البحث بالاهثي هتمام بالأبعاد اللونية وتأثير ها المختلفة عند إجر اء صيانة للمباني الصحية القائمة ووضعها فى الاعتبار عند تصميم مستشفى جديدة.

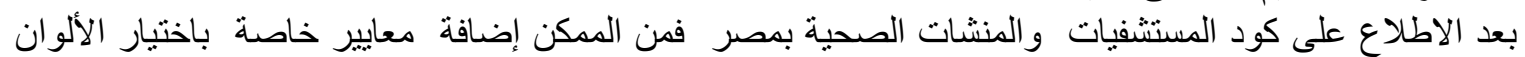

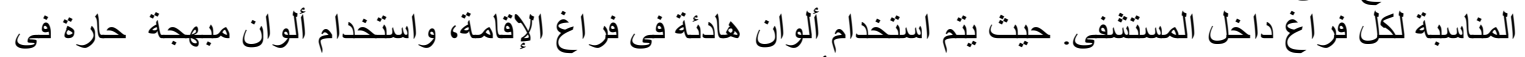

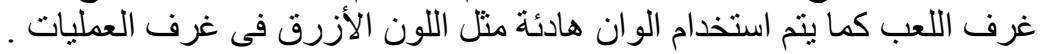

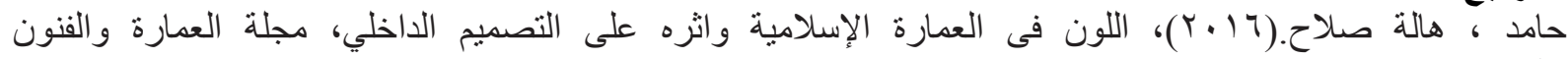

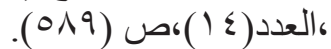

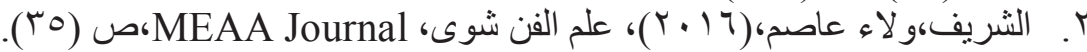

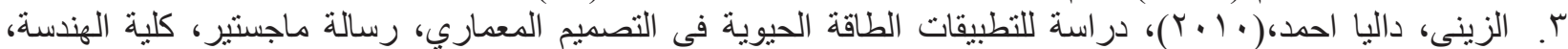
جامعة القاهرة.

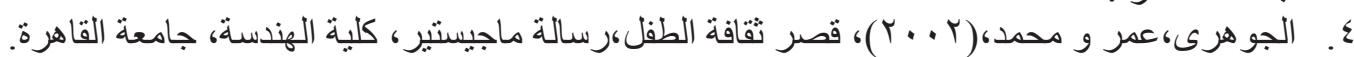

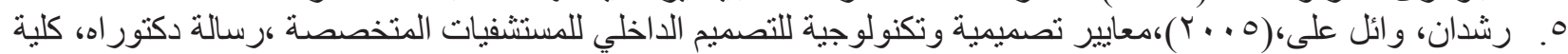

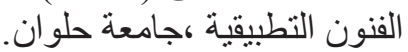

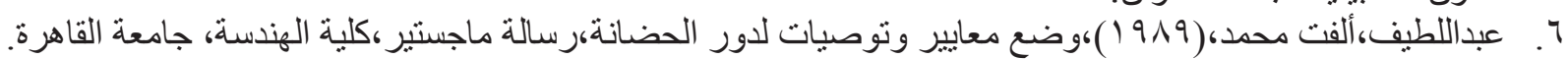

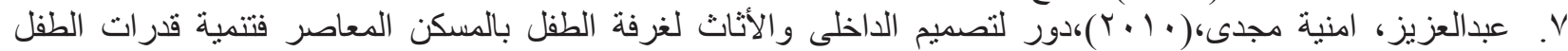

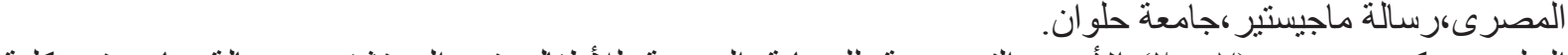

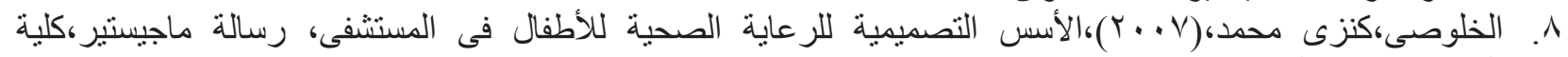
المندسة،جامعة القاهرة

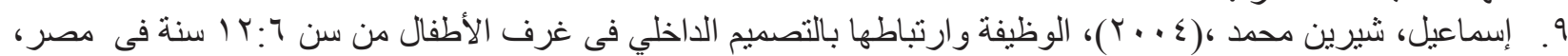

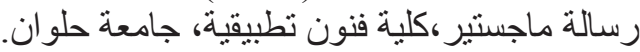

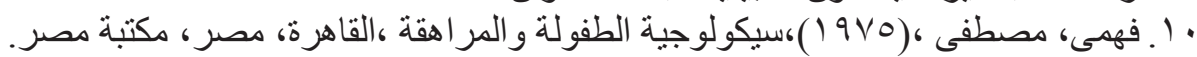

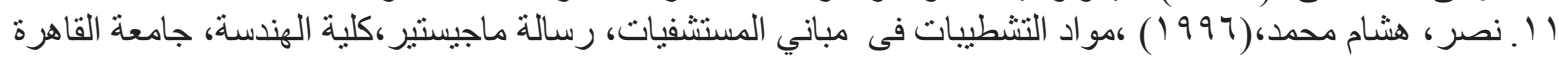

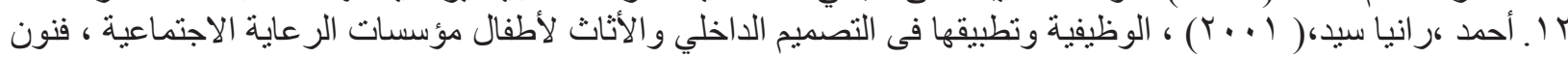

13. Baggs, Sydney,(1997), The Healthy hous,(U.S.A.), Interactive Press.

تطبيقية، جامعة حلوان.

14. Mercier, Patricia,(2007), The Chakra Bible, London, An Hachette Lovre UK Company. 
15. Panero,Julius,(1980),Human Dimenion,Interior Space, New York, Whitney Library of design.

16. Komiske ,Bruce, (2013),Designing The World's Best Children's Hospital 3 , Australia, the images publishing group.

17. Nightingale, Florance, (1859), Notes On Hospitals,London, John W. Parker.

18. Maklin ,Jain,(1992), Hospital interior architecture Creating Healing Environments For Special patient populations, USA, Van No strand Renhold company.

19. Wayne,Ruga,(1997),Desiging For Senses in Healthcare Design,USA, Johnwiley\&Sons,Inc.

20. Olesen,Jacob, (2020), Color Meanings. Retrieved from

21. https://www.color-meanings.com/chakra-colors-the-7-chakras-and-their-meanings/ 